\title{
Analyzing the Curriculum Alignment of Teachers ${ }^{\mathrm{i}}$
}

\author{
Esen Turan-Özpolat ${ }^{1, *}$, Erdal Bay ${ }^{2}$ \\ ${ }^{1}$ Department of Educational Sciences, Faculty of Education, Adıyaman University, Turkey \\ ${ }^{2}$ Department of Educational Sciences, Faculty of Gaziantep Education, Gaziantep University, Turkey
}

Copyright $\mathrm{O} 2017$ by authors, all rights reserved. Authors agree that this article remains permanently open access under the terms of the Creative Commons Attribution License 4.0 International License

\begin{abstract}
The purpose of this research was to analyze the curriculum alignment of teachers in secondary education $5^{\text {th }}$ grade Science course. Alignment levels of teachers in dimensions of acquisition, content, teaching methods and techniques, activity, material and measurement - assessment, and the reasons for their alignment/non-alignment to the curriculum were revealed. The research was carried out using case study model as one of the qualitative research designs. The research was carried out with totally four Science teachers carrying on their duties in three state secondary education schools and one private secondary education school with the highest, medium and lowest success levels determined according to Transition from Primary to Secondary Education (TEOG) exam results in Adiyaman province central district. The data were obtained observing the implementations of teachers they performed at schools and the interviews made with the teachers after these observations. For the analysis of the data, descriptive analysis and content analysis methods were used. Upon analyzing the curriculum alignments of the teachers, it was determined when considered in general that there was no high alignment, and curriculum alignment of all teachers were only at a very high level in "content" dimension; and when considered in details, curriculum alignment of teachers was not present in more than one dimension because there was no expression related to the relevant dimensions in the annual plan in units. Within the scope of the results obtained in the research, it was concluded that teachers considered they administered the curriculum in a way determined by Ministry of National Education (MoNE) during the teaching process, but none of them had a clear knowledge about the definition of program alignment, and their program alignment was not completely fulfilled.
\end{abstract}

Keywords Curriculum Alignment, Curriculum, Science Course, Teacher

\section{Introduction}

It has been noticed that curriculums have not been employed as planned due to some reasons during the implementation process [1-8]. Here, the concept of "curriculum alignment" that means teachers' applying the curriculum as it is or in a way adhering to the original appears. Curriculum alignment is used in the literature in different ways such as the concepts of "curriculum fidelity, curriculum alignment, and coherent curriculum."

Some authors expressed curriculum alignment as the coherence between the elements of the curriculum in a narrow sense. For example, in his study, Scott [9] mentioned the alignment as purpose, teaching and assessment factors of the curriculum. Upon this, English (2000) suggested the concept as a "match or conflict between content and test format, and content and curriculum format," and adopted the idea that curriculum alignment was "a closer match on the test, greater potential development" (Cited in: Burti Jr. [10]). Blank, Porter, \& Smithson [11] were noticed to express curriculum alignment as "state standards that content and regional curriculum framework (targeted curriculum) were correlated with what was taught in the classroom in practice. Similarly, Bhola, Impara and Buckendahl [12] indicated the importance of curriculum alignment, and mentioned it as "the necessity for cognitive demand and classroom content to be compatible with the standards and assessments if students were expected to be competent beyond the standards of the state." Porter, Smithson, Blank, \& Zeidner, [13] and Martone \& Sireci [14] also stated with a similar consideration that assessment and teaching within the scope of curriculum alignment required the analysis of the standards, rights and implementations in classrooms and schools. More clearly, Michalic [15] stated curriculum alignment as determining how well the curriculum was administered when the original curriculum design and curriculum were compared.

When the studies carried out on emphasizing the importance of curriculum alignment and benefits of the curriculum alignment for student success and efficiency of the teaching were analyzed, both Langer (2001) and Koppang (2004) mentioned according to the expression of Center on Instruction/National High School Center [16] that teachers should be within the process of providing the alignments under all conditions in order to define and 
activate specific relationships between teaching and standards and to develop student performance. In their study, Niedermeyer and Yelon [17] discussed curriculum alignment, the process of curriculum alignment and the sources of curriculum alignment. Furthermore, in this study, the researchers mentioned that effects of teaching became more understanding and efficient when teaching and assessment focused on pre-determined targets.

This study carried out upon revealing the status of the concept representing the functionality of the curriculum that directed the implementations at schools, and how the concept was perceived in Turkey was considered to be significant by the researchers. Moreover, this study was also believed to serve for increasing the awareness on curriculum alignment, the subjects' gaining importance during the implementations, and the consideration of on which points and reasons the deviations in alignment were possible to occur.

\subsection{Purpose of the Research}

The purpose of this research was to reveal the coherence between the $5^{\text {th }}$ grade Science course curriculum determined by Ministry of National Education (MoNE), annual plans in units (APiU) and the curriculums Science teachers employed during the educational process. In this sense, the question of what the reasons are for alignment / non-alignment, and alignment dimensions of

- acquisition,

- content,

- teaching methods and techniques;

- activity,

- material, and

- measurement-assessment

in the $5^{\text {th }}$ grade Science courses at secondary schools with high, medium and low success levels according to TEOG (Transition from Primary to Secondary Education) exam success rating was tried to be answered.

\section{Method}

In the research, "multiple holistic case" model on qualitative research design was used. In multiple holistic case study, each case included into the research is discussed holistically in itself, and subsequently compared again [18]. In this sense, the schools were selected according to TEOG exam success ratings obtained from MoNE, and curriculum alignments of Science teachers in each school were analyzed discussing separately.

\subsection{Research Context}

In "Let's Visit and Introduce the World of Living Beings" unit of secondary education $5^{\text {th }}$ grade Science course analyzed within the scope of the research, students' introducing with microscopic beings, fungi, plants and animals, and classifying them according to the similarities and differences were targeted.

\subsection{Study Group}

The study was carried out in Adiyaman province central district in 2014-2015 academic year. Criteria sampling was used in the research. The study group included four Science teachers carrying on their duties in totally four secondary education schools including three state schools and one private school with the highest, medium and lowest success levels determined according to Transition from Primary to Secondary Education (TEOG) exam results in Adiyaman province in 2013-2014 academic year. Among the state schools, Türkiye Petrolleri Secondary School had the highest success level, 50. Y1l Secondary school had medium success level, and TOKI Akşemseddin Secondary School had the lowest success level. Özel Doruk Secondary School was a private secondary school with a high success level.

\subsection{Data Collection Process}

Structured observation and interview techniques were used for collecting the data.

\subsubsection{Observation Process}

Secondary education 5th grade Science course was lectured for 4 hours in a week at schools. In this case, completing the "Let's Visit and Introduce the World of Living Beings" as a 12-hour unit as specified in the curriculum was determined to be completed in 3 weeks in each school. During the observation process, there were some reasons changing curriculum alignment. These reasons were teachers' completing the unit before the pre-determined period not respecting to the course hours specified in the curriculum, cancellation of the courses due to various reasons, and changing the time period specified as 6 each course hour for each section of a unit as different for each section. The observation was fulfilled for 10 hours in Türkiye Petrolleri Secondary School, for 12 hours in 50 Yil Secondary School, for 10 hours in TOKİ Akşemsettin Secondary School, and for 7 hours in Özel Doruk Secondary School.

The observations were recorded with a video recorder. In terms of the observations, there were conflicting course hours between different schools, and this problem was overcome with two cameras, accordingly two observers. One of the observers was the researcher's himself, and the other was an academician specialized in education. The observations fulfilled for each school were explained as below mentioning the time and environment:

\subsubsection{Interview after Observation}

After the observation, semi-structured interview questionnaires including varying number of questions (4-5) related to the observations including the activities they performed in classrooms were addressed to each teacher. 
During the interviews, also the questions supplementary to the questions in the questionnaire were also addressed to the teachers for the understandability of the questions. These questions asked to the teachers for interviews were developed by the researchers as being controlled by an expert. The time for the interviews with the teachers varied between 9 and 29 minutes. A code (such as T1, T2, etc.) was determined for each teacher during the interviews, and the answers of the teachers to the questions were recorded using a video recorder.

\subsection{Data Analysis}

Descriptive analysis and content analysis methods were used for analyzing the data. The purpose in descriptive analysis approach is to present the data obtained at the end of an interview or observation to the reader in an organized way [19]. In content analysis, the process on the basis, is gathering the data similar to each other together within the framework of specific concepts and themes, and interpreting these organizing in a way readers could easily understand [18]. The observation form developed by the researchers was benefited for analyzing the data obtained after the observation. This form was organized to compare MoNE curriculum (MC), annual plan in units (APiU), and teacher implementations (TI). The information in the forms were compared with each other, and expressed with the symbols of "+,", "-," and "/+ (half plus)," and subsequently, the data were analyzed calculating with numerical point values in the system developed by the researcher, and curriculum alignment of the teachers was tried to be determined.

In analysis of the data obtained from the interviews, direct quotations from the expressions of the participants that were considered to be explanatory for sampling the coding were also included. The direct quotations were presented with the numbers determined for the participants, and selection of the expressions representing the similar themes or concepts was regarded. Necessary parts of the expressions related to the addressed questions were presented. However, the symbol of "..." was used in order to indicate that the opinion of the participant continued before or after the expression.

\section{Findings}

In this section of the study, the findings obtained as result of the observations and interviews related to analyzing the coherence of teacher implementations with MoNE curriculum and annual plans in units that teachers benefited were included within the framework of acquisition, content, teaching methods and techniques, activity, material, and measurement-assessment as the dimensions of the curriculum in secondary education schools.

\subsection{Findings Related to "Acquisition" Dimension}

In this section of the findings, alignment levels of MoNE curriculum, annual plan in units and teacher implementation processes within the framework of "acquisition" dimension were explained according to the observation results for all secondary schools included into this research. Moreover, direct quotations including the interview questions and answers related to this dimension were also presented.

In Table 1, it was noticed that 50. Y1l and TOKI Akşemseddin Secondary Schools had the highest average scores (2.3 points) in terms of acquisition dimension. Türkiye Petrolleri and Özel Doruk Secondary School teachers were determined to have lower and equal scores (2 point). General curriculum alignment level of the teachers in all secondary education schools related to the dimension of "acquisition" was calculated to be at a high level (2.15 point).

Table 1. Curriculum alignment levels of all teachers related to acquisition dimension as result of observation

\begin{tabular}{|c|c|c|c|c|}
\hline & Acquisition 1 & Acquisition 2 & Acquisition 3 & Average \\
\hline $\begin{array}{c}\text { Türkiye Petrolleri } \\
\text { Secondary School } \\
\text { Teacher }\end{array}$ & $\begin{array}{l}\text { MC-APiU }(+), \text { MC-TI }(+), \\
\operatorname{APiU}-T I(+)=3+=\mathbf{3} \text { point }\end{array}$ & $\begin{array}{c}\text { MC-APiU }(+), \text { MC-TI }(/+), \\
\text { APiU-TI }(/+)=2+=\mathbf{2} \\
\text { point }\end{array}$ & $\begin{array}{l}\text { MC-APiU (+), MC-TI }(-) \text {, } \\
\text { APiU-TI }(-)=1+=1 \text { point }\end{array}$ & $\begin{array}{c}(“ 3+2+1 " / 3)=\mathbf{2} \text { point } \\
\text { (medium level) }\end{array}$ \\
\hline $\begin{array}{l}\text { 50. Y1l Secondary } \\
\text { School Teacher }\end{array}$ & $\begin{array}{l}\text { MC-APiU }(+), \text { MC-TI }(+), \\
\text { APiU-TI }(+)=3+=\mathbf{3} \text { point }\end{array}$ & $\begin{array}{l}\text { MC-APiU }(+), \text { MC-TI }(+), \\
\text { APiU-TI }(+)=3+=\mathbf{3} \text { point }\end{array}$ & $\begin{array}{l}\text { MC-APiU (+), MC-TI }(-) \text {, } \\
\text { APiU-TI }(-)=1+=1 \text { point }\end{array}$ & $\begin{array}{c}(" 3+3+1 " / 3)=\mathbf{2 . 3} \text { point } \\
\text { (high level) }\end{array}$ \\
\hline $\begin{array}{l}\text { TOKİ Akşemseddin } \\
\text { Secondary School } \\
\text { Teacher }\end{array}$ & $\begin{array}{l}\text { MC-APiU }(+), \text { MC-TI }(+) \text {, } \\
\text { APiU-TI }(+)=3+=\mathbf{3} \text { point }\end{array}$ & $\begin{array}{c}\text { MC-APiU }(+), \text { MC-TI }(/+), \\
\text { APiU-TI }(/+)=2+=\mathbf{2} \\
\text { point }\end{array}$ & $\begin{array}{l}\text { MC-APiU }(+), \text { MC-TI }(/+), \\
\text { APiU-TI }(/+)=2+=\mathbf{2} \text { point }\end{array}$ & $\begin{array}{c}(" 3+2+2 " / 3)=\mathbf{2 . 3} \text { point } \\
\text { (high level) }\end{array}$ \\
\hline $\begin{array}{c}\text { Özel Doruk } \\
\text { Secondary School } \\
\text { Teacher } \\
\end{array}$ & $\begin{array}{l}\text { MC-APiU }(+), \operatorname{MC}-T I(+), \\
\operatorname{APiU}-T I(+)=3+=\mathbf{3} \text { point }\end{array}$ & $\begin{array}{c}\text { MC-APiU }(+), \text { MC-TI }(/+), \\
\text { APiU-TI }(/+)=2+=\mathbf{2} \\
\text { point }\end{array}$ & $\begin{array}{l}\text { MC-APiU (+), MC-TI (-), } \\
\text { APiU-TI }(-)=1+=\mathbf{1} \text { point }\end{array}$ & $\begin{array}{c}(" 3+2+1 " / 3)=\mathbf{2} \text { point } \\
\text { (medium level) }\end{array}$ \\
\hline \multicolumn{4}{|c|}{ Acquisition Dimension General Curriculum Alignment Level } & $\begin{array}{c}(" 2+2.3+2.3+2 " / 4=\mathbf{2 . 1 5} \\
\text { point (high level) }\end{array}$ \\
\hline
\end{tabular}


Interviews were made related to the reasons for the alignment of the teachers with acquisition dimension. Direct quotations from these interviews were presented in the table below.

As could be seen in the Table 2, in the answer to the interview question, $\mathrm{T} 1$ teacher was noticed to express that $\mathrm{s} /$ he forgot to assign homework for project activity, and accordingly, there were acquisitions postponed due to the presence of some non-alignments arisen from time problem. In conclusion, here, when the interview results were analyzed, it was determined that there was a "medium level" alignment between the curriculum and implementation (MC and TI) in "acquisition" dimension in terms of the teachers carrying on their duties in Türkiye Petrolleri Secondary School, and it was determined as result of the interview that partial "deficiency" of the teacher on alignment was arisen from "teacher" and "curriculum."

In the answer given by $\mathrm{T} 2$, it was found that the teacher considered the student level as insufficient for the project activity, some non-alignment was noticed to be experienced due to the anxiety for thinking that the time was insufficient. In conclusion, it was noticed as result of the observation that there was a "high level" alignment between the curriculum and implementation (MC and TI) in "acquisition" dimension in terms of the teachers carrying on their duties in 50. Y1l Secondary School; and it was determined as result of the interview that partial "deficiency" of the teacher on alignment was arisen from "teacher" and "curriculum."

In the answer given by T3, it was found that the teacher assigned project activity as homework, and some non-alignments was noticed to be experienced due to this homework would be assessed in a future date not during the pre-determined time. In conclusion, it was noticed as result of the observation that there was a "high level" alignment between the MoNE curriculum and implementation (MC and TI) in "acquisition" dimension in terms of the teachers carrying on their duties in TOKI Akşemseddin Secondary School, and it was determined as result of the interview that partial "deficiency" of the teacher on alignment was arisen from "teacher."

In the answer of T4 teacher, it was noticed that the curriculum changed every year, the teacher experienced time problem due to busy work tempo, and therefore all acquisitions in the curriculum for this classroom in the present year could not be included. In conclusion, it was noticed as result of the observation that there was a "medium level" alignment between the curriculum and implementation (MC and TI) in "acquisition" dimension in terms of the teachers carrying on their duties in Özel Doruk Secondary School, and it was determined as result of the interview that partial "deficiency" of the teacher on alignment was arisen from "teacher" and "curriculum."

Table 2. "Acquisition" dimension interview questions, quotations from the answers, and themes and codes developed for these

\begin{tabular}{|c|c|c|}
\hline Interview Questions for Teachers & Theme/Code & Quotation \\
\hline $\begin{array}{l}\text { Türkiye Petrolleri Secondary School: } \\
\text { Some of the implementations were included according to the } \\
\text { results of observing the implementations. However, whereas } \\
\text { none of the acquisitions mentioned in the annual plan in } \\
\text { units we had for benefiting in the curriculum were included } \\
\text { during the activities, some of them were only assigned as } \\
\text { homework; for example, the project homework was not } \\
\text { implemented in class. Why? }\end{array}$ & $\begin{array}{l}\text { *Teacher/ } \\
\text { To forget } \\
\text { *Program/ } \\
\text { Lack of time }\end{array}$ & $\begin{array}{l}\text { T1: ... We will include the projects later on, Iforgot to assign as } \\
\text { homework during the previous lesson; therefore, we could not } \\
\text { discuss this subject on a project style during the last course. } \\
\text { Subsequently, I will take time for nearly a week. We have lack } \\
\text { of time. }\end{array}$ \\
\hline $\begin{array}{l}\text { 50. Y1 Secondary School: } \\
\text { According to the results of observing the implementations, } 2 \\
\text { of the acquisitions mentioned in acquisitions sections were } \\
\text { included. However, the acquisition of "the student designs } \\
\text { and presents a project related to the solution of an } \\
\text { environmental problem in close surrounding" was not } \\
\text { included. Why? }\end{array}$ & $\begin{array}{l}\text { *Student/ } \\
\text { Levels of students } \\
\text { *Program/ } \\
\text { Time anxiety }\end{array}$ & $\begin{array}{l}\text { T2: I did not consider the levels of students sufficient for some } \\
\text { activities in this acquisition. Also, I had a little anxiety for time. } \\
\text { Because the time for assessments or homework, presentations } \\
\text { would be limited. }\end{array}$ \\
\hline $\begin{array}{l}\text { Özel Doruk Secondary School: } \\
\text { The acquisition of "categorizing according to similarities } \\
\text { and differences giving examples for the living beings" was } \\
\text { obtained by the students. However, the acquisition of } \\
\text { "searching for the environmental problems appeared as } \\
\text { result of human activities" was provided partly, and the } \\
\text { acquisition of "designing a project related to the solution of } \\
\text { an environmental problem in close surrounding" was not } \\
\text { provided completely. Why? }\end{array}$ & $\begin{array}{c}\text { * Teacher / } \\
\text { Teacher } \\
\text { preference }\end{array}$ & $\begin{array}{l}\text { T4: We have a busy schedule. We carried out some projects } \\
\text { with the students of this classroom in previous years. However, } \\
\text { we have not included all acquisitions for the students of this } \\
\text { classroom this year because I have experienced problems in } \\
\text { time due to the changes in curriculum every year. }\end{array}$ \\
\hline
\end{tabular}


In accordance with the views of all teachers on the dimension of "acquisition," the themes and codes of "related to teacher/to forget" and "related to curriculum/time" (T1), "related to student/student levels" and "related to curriculum/time" (T2), "related to teacher/teacher preference" (T3), and "related to teacher/teacher preference" and "related to curriculum/time" (T4) were obtained in general.

\subsection{The Findings Related to the Dimension of "Content"}

In this section of the findings, alignment levels of MoNE curriculum (MC), annual plan in units (APiU) and teacher implementation (TI) processes within the framework of "content" dimension were explained according to the observation results for all secondary schools included into the research. Moreover, direct quotations including the interview questions and answers related to this dimension were also presented.

In Table 3, it was noticed that curriculum alignments of the teachers at all schools were at a very high level (5 points). Because all these contents were not present in the annual plans in units and these parts were indicated as (-), alignment levels of these teachers carrying on their duties in all secondary education schools related to the dimension of content were only analyzed between MoNE curriculum and teacher implementation. For each content, the alignment between MoNE curriculum and teacher implementation was full. In conclusion, it was determined that curriculum alignment of all teachers were at a very high level with 5 points in terms of content dimension separately, and accordingly, content dimension general curriculum alignment was at a very high level with 5 points.

Table 3. Curriculum alignment levels of all teachers related to the dimension of content as result of observation

\begin{tabular}{|c|c|c|c|c|c|c|}
\hline & $\begin{array}{c}\text { Content 1: } \\
\text { Similarities and } \\
\text { differences of } \\
\text { living beings }\end{array}$ & $\begin{array}{l}\text { Content 2: } \\
\text { Microscopic } \\
\text { beings }\end{array}$ & $\begin{array}{c}\text { Content 3: } \\
\text { Fungi }\end{array}$ & $\begin{array}{l}\text { Content 4: } \\
\text { Plants }\end{array}$ & $\begin{array}{c}\text { Content 5: } \\
\text { Animals }\end{array}$ & Average \\
\hline $\begin{array}{c}\text { Türkiye Petrolleri } \\
\text { Secondary School } \\
\text { Teacher }\end{array}$ & $\begin{array}{c}\text { MC-TI } \\
(+)=1+ \\
=1 \text { point }\end{array}$ & $\begin{array}{l}\text { MC-TI } \\
(+)=1+ \\
=1 \text { point }\end{array}$ & $\begin{array}{l}\text { MC-TI } \\
(+)=1+ \\
=1 \text { point }\end{array}$ & $\begin{array}{l}\text { MC-TI } \\
(+)=1+ \\
=1 \text { point }\end{array}$ & $\begin{array}{l}\text { MC-TI } \\
(+)=1+ \\
=1 \text { point }\end{array}$ & $\begin{array}{c}(1+1+1+1+1 / 5)= \\
5 \text { Point (very high level) }\end{array}$ \\
\hline $\begin{array}{l}\text { 50. Yil Secondary } \\
\text { School Teacher }\end{array}$ & $\begin{array}{l}\text { MC-TI } \\
(+)=1+ \\
=1 \text { point }\end{array}$ & $\begin{array}{l}\text { MC-TI } \\
(+)=1+ \\
=1 \text { point }\end{array}$ & $\begin{array}{l}\text { MC-TI } \\
(+)=1+ \\
=1 \text { point }\end{array}$ & $\begin{array}{l}\text { MC-TI } \\
(+)=1+ \\
=1 \text { point }\end{array}$ & $\begin{array}{l}\text { MC-TI } \\
(+)=1+ \\
=1 \text { point }\end{array}$ & $\begin{array}{c}(1+1+1+1+1 / 5)= \\
5 \text { Point (very high level) }\end{array}$ \\
\hline $\begin{array}{c}\text { TOKİ } \\
\text { Akşemseddin } \\
\text { Secondary School } \\
\text { Teacher }\end{array}$ & $\begin{array}{l}\text { MC-TI } \\
(+)=1+ \\
=1 \text { point }\end{array}$ & $\begin{array}{l}\text { MC-TI } \\
(+)=1+ \\
=1 \text { point }\end{array}$ & $\begin{array}{l}\text { MC-TI } \\
(+)=1+ \\
=1 \text { point }\end{array}$ & $\begin{array}{c}\text { MC-TI }(+)= \\
1+ \\
=1 \text { point }\end{array}$ & $\begin{array}{l}\text { MC-TI } \\
(+)=1+ \\
=1 \text { point }\end{array}$ & $\begin{array}{c}(1+1+1+1+1 / 5)= \\
5 \text { Point (very high level) }\end{array}$ \\
\hline $\begin{array}{c}\text { Özel Doruk } \\
\text { Secondary School } \\
\text { Teacher }\end{array}$ & $\begin{array}{l}\text { MC-TI } \\
(+)=1+ \\
=1 \text { point }\end{array}$ & $\begin{array}{l}\text { MC-TI } \\
(+)=1+ \\
=1 \text { point }\end{array}$ & $\begin{array}{l}\text { MC-TI } \\
(+)=1+ \\
=1 \text { point }\end{array}$ & $\begin{array}{c}\text { MC-TI }(+)= \\
1+ \\
=1 \text { point }\end{array}$ & $\begin{array}{l}\text { MC-TI } \\
(+)=1+ \\
=1 \text { point }\end{array}$ & $\begin{array}{c}(1+1+1+1+1 / 5)= \\
5 \text { Point (very high level) }\end{array}$ \\
\hline \multicolumn{4}{|c|}{ Content Dimension General Curriculum Alignment Level } & \multicolumn{3}{|c|}{$“ 5+5+5+5 ” / 4=\mathbf{5}$ point (very high level) } \\
\hline
\end{tabular}


The interviews were made related to the reasons for the alignment of the teachers with content dimension. Direct quotations from these interviews were presented in the table below.

In the answer of $\mathrm{T} 1$ teacher, it was noticed that the teacher was conscious about including all content, and the annual plan in units was not prepared by the self. This indicated that the teacher was fully aligned with the curriculum prepared by MoNE in terms of content, the teacher was aware that the content was not included in the annual plan in units, and the teacher also had no responsibility for the process of preparing the annual plan in units. For that reason, there was some non-alignment arisen from teacher's not preparing the annual plan in units. In conclusion, it was noticed as result of the observation that there was a "very high level" alignment between the curriculums in "content" dimension in terms of the teachers carrying on their duties in Türkiye Petrolleri Secondary School, and it was determined as result of the interview that partial "deficiency" of the teacher on alignment was arisen from "teacher."

In the answer of $\mathrm{T} 2$ teacher, it was noticed that the teacher was conscious about including all content, and the annual plan in units was not prepared by the self. This indicated that the teacher was fully aligned with the curriculum prepared by MoNE in terms of content, the teacher was aware that the content was not included in the annual plan in units, and the teacher also felt regret on having no responsibility for the process of preparing the annual plan in units. Moreover, the teacher also mentioned that $\mathrm{s} /$ he could prepare the plan according to the conditions of the school and environment in case of preparing the annual plan in units, so that $\mathrm{s} / \mathrm{he}$ could make changes related to the grades to be lectured being away from the curriculum while administering the curriculum, and s/he could also eliminate the ones not possible to be practiced in the plan and change the methods, as well. In conclusion, it was noticed as result of the observation that there was a "very high level" alignment between the curriculums in "content" dimension in terms of the teachers carrying on their duties in 50. Y1l Secondary School, and it was determined as result of the interview that partial "deficiency" of the teacher on alignment was arisen from "teacher."

In the answer given by T3 teacher, the teacher was understood not to be influenced from content's not being included into the annual plan in units apart from MoNE curriculum, and this was not regarded by the teacher, even included. In conclusion, it was noticed as result of the observation that there was a "very high level" alignment between the curriculums in "content" dimension in terms of the teachers carrying on their duties in TOKI Akşemseddin Secondary School, and it was determined as result of the interview that partial "deficiency" of the teacher on alignment was arisen from "teacher."

In the answer of T4 teacher, it was noticed that the teacher was fully aware of not including all the expressions in content section of annual plan in units, and this was arisen from his/her experience and following the curriculum permanently, namely from the teacher. In conclusion, it was noticed as result of the observation that there was a "very high level" alignment between the curriculums in "content" dimension in terms of the teachers carrying on their duties in Özel Doruk Secondary School, and it was determined as result of the interview that partial "deficiency" of the teacher on alignment was arisen from "teacher."

Table 4. "Content" dimension interview questions, quotations from the answers, and themes and codes developed for these

\begin{tabular}{|c|c|c|}
\hline Interview Questions for Teachers & Theme/Code & Quotation \\
\hline $\begin{array}{l}\text { Türkiye Petrolleri Secondary School: } \\
\text { All content determined by MoNE was } \\
\text { included. However, the contents were not } \\
\text { included in the annual plan in units. What } \\
\text { would you like to tell about this? }\end{array}$ & $\begin{array}{l}\text { *Teacher/ } \\
\text { Preparing the annual } \\
\text { plan in units }\end{array}$ & $\begin{array}{l}\text { T1: Yes. I cannot answer this because I did not prepare the annual plan in } \\
\text { units by myself. }\end{array}$ \\
\hline $\begin{array}{l}\text { 50. Y1 Secondary School: } \\
\text { All content determined by MoNE was } \\
\text { included. However, the contents were not } \\
\text { included in the annual plan in units. What } \\
\text { would you like to tell about this? }\end{array}$ & $\begin{array}{l}\text { *Related to teacher/ } \\
\text { Teacher preference }\end{array}$ & $\begin{array}{l}\text { T2: ... We use the annual plan in units prepared by the group teachers of } \\
\text { another school. I consider that I should prepare the annual plan of the } \\
\text { present year according to the school and environment conditions instead of } \\
\text { using this. I also consider that this will make me be away from the curriculum } \\
\text { while administering it. Because I directly take the plan as it is, I make no } \\
\text { change for the grade I will lecture. For example, I can omit the one I cannot } \\
\text { implement. I can also change the methods. }\end{array}$ \\
\hline $\begin{array}{l}\text { TOKİ Akşemseddin Secondary School: } \\
\text { All content determined by MoNE was } \\
\text { included. However, the contents were not } \\
\text { included in the annual plan in units. What } \\
\text { would you like to tell about this? }\end{array}$ & $\begin{array}{l}\text { * Related to teacher/ } \\
\text { Teacher preference }\end{array}$ & $\begin{array}{l}\text { T3: I don't like adhering to the plan as it is, I provide what should be } \\
\text { provided to students whether it is on the plan or not. The plan is not } \\
\text { functional for me. Namely, something is not possible for me to be essential } \\
\text { even it is written in the annual plan. }\end{array}$ \\
\hline $\begin{array}{l}\text { Özel Doruk Secondary School: } \\
\text { All expressions in content section of the } \\
\text { MoNE curriculum were expressed in the } \\
\text { classroom. Did you manage this } \\
\text { consciously? And the content was not } \\
\text { included in the annual plan in units. What } \\
\text { would you like to tell about this? }\end{array}$ & $\begin{array}{l}\text { * Related to teacher/ } \\
\text { Teacher preference }\end{array}$ & $\begin{array}{l}\text { T4: Yes, I am fully conscious about this. This is related to my experience, this } \\
\text { was arisen from my being informed on content due to following the } \\
\text { curriculum permanently. Maybe I did not to notice that the content was not } \\
\text { included in the annual plan in units. Idid not prepare the annual plan in } \\
\text { units. }\end{array}$ \\
\hline
\end{tabular}


In accordance with the views of all teachers on the dimension of "content," the themes and codes of "related to teacher/preparing the annual plan in units" and "related to curriculum/time" (T1), and "related to teacher/teacher preference" (T2, T3, T4) were obtained in general.

\subsection{The Findings Related to the Dimension of Teaching Methods and Techniques}

In this section of the findings, curriculum alignment levels of the teachers were not regarded because there was no expression related to this dimension in the annual plan in units that MoNE curriculum and all secondary education teachers benefited within the framework of "teaching methods and techniques" dimension for all secondary education schools studied according to the observation results. Accordingly, number and types of the teaching methods and techniques used by all secondary education teachers were included in this section, and direct quotations related to the interview questions and answers of the teachers on teaching methods and techniques were also presented.

In Table 5, when teaching methods and techniques used by the teachers carrying on their duties in the observed schools in Science course were analyzed, it was noticed that there were totally 5 techniques used during the educational process as direct instruction, question-answer, research-analysis, self-study and group study, and all teachers benefited from direct instruction, question-answer and research-analysis methods. In the Table, self-study method was noticed to be included by all teachers apart from Özel Doruk Secondary Education School teacher. Finally, when group-study method was analyzed, it was determined that this method was only administered by the teacher of 50 Y1l Secondary Education School with medium success level, and not performed by the other teachers. In conclusion, the most variety of methods (5 methods) was included by the teacher of 50. Y1l Secondary Education School, and the subsequent were Türkiye Petrolleri and TOKI Akşemseddin Secondary Education School teachers with equal numbers (4 methods), and the least variety was noticed in Özel Doruk Secondary Education School teacher (3 methods). Interviews related to the reasons for the alignment of teachers in "content" dimension were made.
Direct quotations from these interviews were presented below.

In the answer given by $\mathrm{T} 1$, it was noticed that the teacher did not include group-study method within the framework of teaching methods and techniques, performed group-study method that was possible to be appropriate with the unit at school s/he carried on his/her duty in previous years, s/he avoided this method because students' coming together for studying was hard, performing the method was not forgotten, but the time was not sufficient.. It was also determined that the teacher mentioned coming together for sightseeing technique was hard, they had no chance to go during the course hour, and it was not possible to complete the trip in one hour time. While explaining this, the teacher also expressed that public transportation vehicles were required for bringing students to the place to be visited, such vehicles never arrived on time, and a plan should be made for the sightseeing. The teacher who continued to explain the difficulty of implementing sightseeing technique expressed this difficulty as teacher's being responsible from everything, requiring the permission of parents, receiving the permission of institution if the place to be visited was an institution. In terms of the experiment technique, the experiment on yeast fungus within the scope of the unit took at least 20 minutes, six-hat technique and this experiment was possible to be performed within 1 course hour, but $\mathrm{s} /$ he would perform these later. The teacher was also noticed not to make any explanations on observation and project techniques that were not included in educational frameworks by the teacher. So that the teacher was determined to express alignment deficiency experienced in education dimension as arisen from time (related to curriculum), parents (related to other situations), school, teacher, institutional permission (related to other situations), and etc. In conclusion, "no alignment" was regarded between the curriculums (MoNE curriculum and annual plan in units) in this dimension for the teacher carrying on his/her duty in Türkiye Petrolleri Secondary Education School, and it was noticed as result of the interview that educational deficiencies the teacher experienced in this dimension were arisen from "time" (related to curriculum), "parents" (related to other situations), "school," "teacher," "institutional permission" (related to other situations), etc.

Table 5. Teaching methods and techniques used by all secondary education teachers during the observation process

\begin{tabular}{|c|c|c|c|c|c|c|}
\hline Schools & $\begin{array}{c}\text { Direct } \\
\text { instruction } \\
\text { method } \\
\end{array}$ & $\begin{array}{l}\text { Question-answer } \\
\text { method }\end{array}$ & $\begin{array}{l}\text { Research-analysis } \\
\text { method }\end{array}$ & $\begin{array}{l}\text { Self-study } \\
\text { method }\end{array}$ & $\begin{array}{l}\text { Group-study } \\
\text { method }\end{array}$ & Total \\
\hline $\begin{array}{l}\text { Türkiye Petrolleri } \\
\text { Secondary Education } \\
\text { School }\end{array}$ & $\checkmark$ & $\checkmark$ & $\checkmark$ & $\checkmark$ & - & 4 \\
\hline $\begin{array}{l}\text { 50. Y1l Secondary } \\
\text { Education School }\end{array}$ & $\checkmark$ & $\checkmark$ & $\checkmark$ & $\checkmark$ & $\checkmark$ & 5 \\
\hline $\begin{array}{l}\text { TOKİ Akşemseddin } \\
\text { Secondary Education } \\
\text { School }\end{array}$ & $\checkmark$ & $\checkmark$ & $\checkmark$ & $\checkmark$ & - & 4 \\
\hline $\begin{array}{l}\text { Özel Doruk Secondary } \\
\text { Education School }\end{array}$ & $\checkmark$ & $\checkmark$ & $\checkmark$ & - & - & 3 \\
\hline
\end{tabular}


Table 6. "Teaching method and techniques" dimension interview questions, quotations from the answers, and themes and codes developed for these

\begin{tabular}{|c|c|c|}
\hline Interview Questions for Teachers & Theme/Code & Quotation \\
\hline $\begin{array}{l}\text { Türkiye Petrolleri Secondary Education School: } \\
\text { In general, direct instruction, question-answer, } \\
\text { research-analysis, self-study and concept map as } \\
\text { teaching methods and techniques were included. } \\
\text { However, group-study method that was possible to } \\
\text { be compatible with the subject, experiment and } \\
\text { sightseeing-observation techniques, six-hats } \\
\text { technique, and project preparation included in the } \\
\text { course book were not included (only assigned as } \\
\text { homework). }\end{array}$ & $\begin{array}{l}\text { *Related to curriculum/ } \\
\text { Time } \\
\text { *Related to other } \\
\text { situations/ } \\
\text { Permission of parents } \\
\text { and institutional } \\
\text { permission } \\
\text { *Related to school/ } \\
\text { No vehicle } \\
\text { *Related to teacher/ } \\
\text { Teacher preference }\end{array}$ & $\begin{array}{l}\text { T1: We will perform all these in the classroom (later at an } \\
\text { appropriate time).Let me explain so that we performed } \\
\text { group-study method in old schools. (However) because the places } \\
\text { students come from are different (in groups), it is a problem for } \\
\text { them to study coming together. Of course, there are teachers } \\
\text { performing this; it is a bit difficult to forget (methods and } \\
\text { techniques for implementation), I did not forget, either; I had no } \\
\text { time. On sightseeing, I considered that it was hard to come } \\
\text { together, and we had no chance to go during the course hour. We } \\
\text { cannot fulfill sightseeing in one hour, the service bus do not come } \\
\text { on time, I have to make a plan, a vehicle is necessary; a public } \\
\text { transport vehicle. Teacher is responsible from everything; we } \\
\text { have to obtain the permission of parents and institutional } \\
\text { permission if we will visit an institution. For the experiment, the } \\
\text { yeast fungus experiment takes at least } 20 \text { minutes. For that } \\
\text { reason, it is possible to perform six-hat technique and experiment } \\
\text { in } 1 \text { hour (at a later time). }\end{array}$ \\
\hline $\begin{array}{l}\text { 50. Y1 Secondary Education School: } \\
\text { Direct instruction, question-answer, } \\
\text { research-analysis, group-study and self-study } \\
\text { (project and poster) as teaching methods and } \\
\text { techniques were most frequently included. } \\
\text { However, experiment and sightseeing-observation } \\
\text { techniques possible to be coherent with the subject } \\
\text { were not included. Why? }\end{array}$ & $\begin{array}{l}\text { *Related to school/ } \\
\text { Material deficiency for } \\
\text { the experiment } \\
\text { * Related to other } \\
\text { situations / } \\
\text { Institutional permission }\end{array}$ & $\begin{array}{l}\text { T2: I wanted to use a microscope for the experiment; however, it } \\
\text { had no lens, I asked to other Science teachers, but I could not } \\
\text { perform when I could not find. In terms of } \\
\text { sightseeing-observation method, I could not include this } \\
\text { implementation because the institutional permission process was } \\
\text { challenging. }\end{array}$ \\
\hline $\begin{array}{l}\text { TOKI Akssemseddin Secondary Education School: } \\
\text { Direct instruction, question-answer, concept map } \\
\text { technique, research-analysis and self-study } \\
\text { methods ("carrying out project homework" just as } \\
\text { the homework) were included as teaching methods } \\
\text { and techniques. However, group-study methods, } \\
\text { sightseeing-observation technique, and six-hat } \\
\text { technique mentioned in the annual plan in units } \\
\text { possible to be coherent with the subject were not } \\
\text { performed in classroom (only assigned as } \\
\text { homework). Why? }\end{array}$ & $\begin{array}{l}\text { * Related to other } \\
\text { situations / } \\
\text { Financial possibilities of } \\
\text { students (parents), } \\
\text { Permission of parents, } \\
\text { institutional permission } \\
\text { (correspondence) } \\
\text { *Related to school/ } \\
\text { No vehicle (at school) } \\
\text { *Related to student/ } \\
\text { Students' not studying } \\
\text { *Related to curriculum/ } \\
\text { Time }\end{array}$ & $\begin{array}{l}\text { T3: That is what I mention as deficiency, I express by this way. } \\
\text { For example, I would like to introduce the plants to the students in } \\
\text { nature, but how we will go there, and most importantly, the } \\
\text { students have no financial possibilities, we have o vehicle. Maybe } \\
\text { we will request from Directorate of National Education, but there } \\
\text { will be more problems, there are some parents who do not give } \\
\text { permission or we can have correspondence problems. } \\
\text { Group-study was possible to be performed to the students; Itried } \\
\text { it in previous years. However, the students do not study } \\
\text { adequately; they do not come to school as prepared to their } \\
\text { lessons. But, time is the most important problem, I cannot take } \\
\text { time. }\end{array}$ \\
\hline $\begin{array}{l}\text { Özel Doruk Secondary Education School: } \\
\text { Direct instruction, question-answer, } \\
\text { research-analysis method, and concept map as } \\
\text { teaching methods and techniques were most } \\
\text { frequently included. However, self-study methods, } \\
\text { group-study method, sightseeing and observation } \\
\text { technique, and six-hat technique mentioned in the } \\
\text { course book possible to be coherent with the } \\
\text { subject were not performed in classroom. Why? }\end{array}$ & $\begin{array}{l}* \text { Related to teacher/ } \\
\text { Teacher preference }\end{array}$ & $\begin{array}{l}\text { T4: I considered that this unit could be lectured better in this way. } \\
\text { I performed other methods and techniques in previous units, and } \\
\text { in this unit I included group-study method like a repetition } \\
\text { method in a two-hour lesson soon after the observation, namely } \\
\text { after completing the unit. I grouped failed students together as } \\
\text { mixed, and I performed. }\end{array}$ \\
\hline
\end{tabular}

In the answer of $\mathrm{T} 2$ teacher, it was noticed that the teacher did not include group-study method within the framework of education, $\mathrm{s} / \mathrm{h}$ e wanted to use microscope for for the experiment possible to be appropriate with the unit, but $\mathrm{s} / \mathrm{he}$ could not find, also could not include sightseeing-observing method due to the presence of institutional procedures and its being challenging. This indicated that the teacher was in a low alignment with the annual plan in units and curriculum prepared by MoNE in terms of education, and administered the educational activities not included in the curriculum and plan during the process. Furthermore, the teacher was also noticed to explain the deficiency related to education in terms of educational situations dimension as being arisen from the reasons such as lack of material (related to school) and institutional procedures (related to other situations), etc. In conclusion, "no alignment" was regarded between the curriculums (MoNE curriculum and annual plan in units) in "teaching methods and techniques" dimension for the teacher carrying on his/her duty in 50. Yil Secondary Education School, and it was noticed as result of the interview that educational deficiencies the teacher experienced in this dimension were arisen from "related to school," and "related to other situations" (institutional permission), etc.

In the answer of $\mathrm{T} 3$ teacher, the teacher was noticed not 
to include group-study method because the students do not prepare well and study adequately, not to include sightseeing-observation method because taking the permission of the parents were hard and experiencing difficulty in supplying vehicles from relevant institutions, and the presence of financial difficulties. In conclusion, "no alignment" was regarded between the curriculums in this dimension for the teacher carrying on his/her duty in TOKI Akşemseddin Secondary Education School, and it was noticed as result of the interview that educational deficiencies the teacher experienced in this dimension were arisen from "related to student," and "related to other situations" (permission of parents, socio-economic status of parents, institutional procedures), etc.

In the answer given by $\mathrm{T} 4$ teacher, it was noticed in terms of self-study method, group-study method, sightseeing-observation and six-hat techniques considered to be appropriate with the unit but not included into the process that these methods and techniques were included in previous units, especially group-study method was especially included in subsequent 2 course hours soon after the observation of this unit, and while administering this method, the groups were created mixing successful and unsuccessful students. In conclusion, "no alignment" was regarded between the curriculums in this dimension for the teacher carrying on his/her duty in Özel Doruk Secondary Education School, and it was noticed as result of the interview that educational deficiencies the teacher experienced in this dimension were arisen from "related to teacher" (teacher preference).

In accordance with the views of all teachers on the dimension of "teaching methods and techniques," the themes and codes of "related to curriculum/time," "related to other situations/permission of parents and institutional permission," "related to school/no vehicle," and "related to teacher/teacher preference" (T1), "related to school/ lack of material for the experiment," "related to other situations/institutional permission" (T2), "related to other situations/financial possibilities of the student (parents), permission of parents, institutional permissions (correspondence)," "related to school/no vehicle (at school)," "related to student/student's not studying," "related to curriculum/time" (T3), and "related to teacher/teacher preference" (T4) were obtained in general.

\subsection{The Findings Related to the Dimension of Activity}

In this section of the findings, alignment levels of MoNE curriculum, annual plan in units and teacher implementation processes within the framework of "activity" dimension were explained according to the observation results for all secondary schools included into the research. Moreover, direct quotations including the interview questions and answers related to this dimension were also presented

Table 7. The activities all secondary education teachers used during the observation process

\begin{tabular}{|c|c|c|c|c|}
\hline & $\begin{array}{c}\text { Türkiye Petrolleri } \\
\text { Secondary Education } \\
\text { School }\end{array}$ & $\begin{array}{c}\text { 50. Yil } \\
\text { Secondary Education } \\
\text { School }\end{array}$ & $\begin{array}{c}\text { TOKİ Akşemseddin } \\
\text { Secondary Education } \\
\text { School }\end{array}$ & $\begin{array}{c}\text { Özel Doruk } \\
\text { Secondary } \\
\text { Education School }\end{array}$ \\
\hline $\begin{array}{l}\text { Activity 1. Let's observe the microscopic } \\
\text { beings. }\end{array}$ & $\begin{array}{c}\text { APiU-TI } \\
(-)\end{array}$ & $\begin{array}{c}\text { APiU-TI } \\
(-)\end{array}$ & $\begin{array}{c}\text { APiU-TI } \\
(-)\end{array}$ & $\begin{array}{c}\text { APiU-TI } \\
(-)\end{array}$ \\
\hline $\begin{array}{l}\text { Activity 2. Which parts do flowering } \\
\text { plants include? }\end{array}$ & $\begin{array}{l}\text { APiU-TI } \\
(-)\end{array}$ & $\begin{array}{l}\text { APiU-TI } \\
(+)\end{array}$ & $\begin{array}{l}\text { APiU-TI } \\
(+)\end{array}$ & $\begin{array}{l}\text { APiU-TI } \\
(+)\end{array}$ \\
\hline $\begin{array}{l}\text { Activity 3. Let's observe the plants in our } \\
\text { environment. }\end{array}$ & $\begin{array}{l}\text { APiU-TI } \\
(-)\end{array}$ & $\begin{array}{l}\text { APiU-TI } \\
(-)\end{array}$ & $\begin{array}{l}\text { APiU-TI } \\
(-)\end{array}$ & $\begin{array}{l}\text { APiU-TI } \\
(+)\end{array}$ \\
\hline Activity 4. I observe in a natural area. & - & $\begin{array}{c}\text { APiU-TI } \\
(-)\end{array}$ & $\begin{array}{l}\text { APiU-TI } \\
(-)\end{array}$ & $\begin{array}{l}\text { APiU-TI } \\
(-)\end{array}$ \\
\hline $\begin{array}{lccc}\text { Activity 5. Let's discover through } \\
\text { experimenting (Fungi) }\end{array}$ & - & $\begin{array}{l}\text { APiU-TI } \\
(-)\end{array}$ & $\begin{array}{c}\text { APiU-TI } \\
(+)\end{array}$ & $\begin{array}{l}\text { APiU-TI } \\
(-)\end{array}$ \\
\hline $\begin{array}{l}\text { Activity 6. Let's discover through } \\
\text { experimenting (Microscopic beings) }\end{array}$ & - & $\begin{array}{l}\text { APiU-TI } \\
(-)\end{array}$ & $\begin{array}{l}\text { APiU-TI } \\
(-)\end{array}$ & $\begin{array}{l}\text { APiU-TI } \\
(-)\end{array}$ \\
\hline Activity 7. Let's prepare a project & - & $\begin{array}{l}\text { APiU-TI } \\
(+)\end{array}$ & $\begin{array}{l}\text { APiU-TI } \\
(-)\end{array}$ & $\begin{array}{l}\text { APiU-TI } \\
(-)\end{array}$ \\
\hline $\begin{array}{l}\text { Activity } 8 \text {. Is the environment you live in } \\
\text { changing? }\end{array}$ & - & $\begin{array}{l}\text { APiU-TI } \\
(+)\end{array}$ & $\begin{array}{l}\text { APiU-TI } \\
(-)\end{array}$ & $\begin{array}{c}\text { APiU-TI } \\
(-)\end{array}$ \\
\hline Activity 9. Let's observe the air pollution. & - & $\begin{array}{l}\text { APiU-TI } \\
(-)\end{array}$ & $\begin{array}{l}\text { APiU-TI } \\
(-)\end{array}$ & $\begin{array}{l}\text { APiU-TI } \\
(-)\end{array}$ \\
\hline $\begin{array}{l}\text { Activity 10. Let's prepare a poster. The } \\
\text { environment on news. }\end{array}$ & - & $\begin{array}{c}\text { APiU-TI } \\
(+)\end{array}$ & $\begin{array}{c}\text { APiU-TI } \\
(-)\end{array}$ & $\begin{array}{c}\text { APiU-TI } \\
(-)\end{array}$ \\
\hline Average & $\mathbf{0}$ (non-aligned) & $\begin{array}{c}\text { (Activity } 2,7,8,10) \\
(4+)=4 \text { point }(\text { low } \\
\text { level) }\end{array}$ & $\begin{array}{c}\text { (Activity } 2,5):(2+)= \\
2 \text { point }(\text { very low } \\
\text { level) }\end{array}$ & $\begin{array}{c}\text { (Activity } 2,3):(2+) \\
=\mathbf{2} \text { point }(\text { very low } \\
\text { level) }\end{array}$ \\
\hline
\end{tabular}


In Table 7, the alignment was regarded between ApiU and TI because the activities were not included in MoNE curriculum when the alignment levels related to Activity 1, Activity 2 and Activity 3 were analyzed in terms of the teacher carrying on his/her duty in Türkiye Petrolleri Secondary Education School with high success level. In this sense, when the alignment between the annual plan in units and teacher implementation was analyzed for Activity 1, Activity 2 and Activity 3, non-alignment was noticed in all activities. In conclusion, curriculum alignment of this teacher in terms of activity was noticed to be non-aligned in general.

Alignment levels of the teachers carrying on their duties in 50. Y1l Secondary Education School, TOKI AKşemseddin Secondary Education School and Özel Doruk Secondary Education School for Activity 1, Activity 2, Activity 3, Activity 4, Activity 5, Activity 6, Activity 7, Activity 8, Activity 9, and Activity 10 were analyzed between annual plan in units and teacher implementation. The reason for this was having no information related to the activities in MoNE curriculum. In this sense, when alignment levels were analyzed, the teacher carrying on their duty in 50. Y1l Secondary Education School with medium success level had alignment with Activity 2, Activity 7, Activity 8 , and Activity 10 . In conclusion, curriculum alignment of the teacher in terms of the activity was noticed to be at a low level with 4 points in general.

It was noticed when curriculum alignment levels of the teacher carrying on his/her duty in TOKI Akşemseddin Secondary Education School with low success level that the teacher had only alignment in Activity 2 and Activity 5. In conclusion, curriculum alignment of the teacher in terms of activity was found to be at a very low level with 2 points in general.

It was noticed when curriculum alignment levels of the teacher carrying on his/her duty in Özel Doruk Secondary Education School with low success level that the teacher had only alignment in Activity 2 and Activity 3. In conclusion, curriculum alignment of the teacher in terms of activity was found to be at a very low level with 2 points in general. Interviews were made related to the reasons Interviews related to the reasons for the alignment of teachers in "activity" dimension were made. Direct quotations from these interviews were presented below.

As could be seen in Table 8, it was noticed in the answer of $\mathrm{T} 1$ teacher that $\mathrm{s} / \mathrm{he}$ postponed the project activity, experienced time problem for all activities, and therefore, non-alignment arisen from these reasons was experienced. In conclusion, as result of the observation, there was "no alignment" between the curriculums in dimension of "activity" for the teacher carrying on his/her duty in Türkiye Petrolleri Secondary Education School, and it was noticed as result of the interview that educational deficiencies the teacher experienced in this dimension were arisen from the reason as "related to curriculum" (time).

In the answer of $\mathrm{T} 2$ teacher, $\mathrm{s} /$ he was noticed to mention the presence of non-alignment for the activities related to the reasons arisen from not considering the activities appropriate for student level, experiencing lack of material, and having the anxiety of time problem considering it as insufficient. In conclusion, as result of the observation, there was "low level of alignment" between the curriculums in dimension of "activity" for the teacher carrying on his/her duty in 50 Y1l Secondary Education School, and it was noticed as result of the interview that educational deficiencies the teacher experienced in this dimension were arisen from the reasons as "related to school" (lack of material for the activity), "related to students" (student level), and "related to curriculum (time).

Table 8. "Activity" dimension interview questions, quotations from the answers, and themes and codes developed for these

\begin{tabular}{|c|c|c|}
\hline Interview Questions for Teachers & Theme/Code & Quotation \\
\hline $\begin{array}{c}\text { Türkiye Petrolleri Secondary Education School: } \\
\text { You did not include any of the activities mentioned in the annual plan in } \\
\text { units. Why? }\end{array}$ & $\begin{array}{l}\text { *Related to } \\
\text { curriculum/ } \\
\text { Time }\end{array}$ & $\begin{array}{c}\text { T1: I will include the projects later. However, } \\
\text { we have time problem for all. }\end{array}$ \\
\hline $\begin{array}{l}\text { 50. Y1l Secondary Education School: } \\
\text { You did not include several activities in annual plan in units apart from } \\
\text { some (preparing a project/recycled paper production, parts of a flowering } \\
\text { plant, presenting on a flower model, is the environment you live in } \\
\text { changing?/preparing a slide presentation related to the change of } \\
\text { environment you live in, let's prepare a poster: environment on } \\
\text { news/preparing posters including the news on environment) in the } \\
\text { classroom. Why? }\end{array}$ & $\begin{array}{l}\text { *Related to school/ } \\
\text { Lack of material for } \\
\text { the activity } \\
\text { *Related to student/ } \\
\text { Student level } \\
\text { *Related to } \\
\text { curriculum/ } \\
\text { Time }\end{array}$ & $\begin{array}{l}\text { T2: We cannot perform some activities; it is } \\
\text { due to lack of materials. I also did not include } \\
\text { some activities because I did not consider } \\
\text { them as appropriate to student level. Also I } \\
\text { had anxiety for time, though little. }\end{array}$ \\
\hline $\begin{array}{l}\text { TOKİ Akşemseddin Secondary Education School: } \\
\text { You did not include several activities in annual plan in units apart from } \\
\text { two (parts of a flowering plant, presenting on a flower model and let's } \\
\text { discover through experimenting -fungi-/analyzing the fungus in } \\
\text { microscope) in the classroom. Why? }\end{array}$ & $\begin{array}{l}\text { *Related to school/ } \\
\text { Lack of material }\end{array}$ & $\begin{array}{c}\text { T3: We cannot perform some activities due to } \\
\text { the lack of materials at school. }\end{array}$ \\
\hline $\begin{array}{l}\text { Özel Doruk Secondary Education School: } \\
\text { You did not include several activities in annual plan in units apart from } \\
\text { two (analyzing a real flowering plant and let's observe the plants in our } \\
\text { environment/planting bean, chickpea or lentil seeds and observing plant } \\
\text { growth) in the classroom. Why? }\end{array}$ & $\begin{array}{l}\text { *Related to student/ } \\
\text { Student level }\end{array}$ & $\begin{array}{l}\text { T4: I do not include the activities I regard as } \\
\text { inappropriate to the student level during the } \\
\text { process. }\end{array}$ \\
\hline
\end{tabular}


In the answer of $\mathrm{T} 3$ teacher, $\mathrm{s} / \mathrm{he}$ was noticed to mention the presence of a non-alignment arisen from the reason of lack of material. In conclusion, as result of the observation, there was a "very low level" alignment between the curriculums in dimension of "activity" for the teacher carrying on his/her duty in TOKI Akşemseddin Secondary Education School, and it was noticed as result of the interview that educational deficiencies the teacher experienced in this dimension were arisen from "related to school" (lack of material).

In the answer of T4 teacher, s/he was noticed to mention the presence of a non-alignment arisen from teacher's considering that the activities were inappropriate to the level of students. In conclusion, as result of the observation, there was a "very low level" alignment between the curriculums in dimension of "activity" for the teacher carrying on his/her duty in Özel Doruk Secondary Education School, and it was noticed as result of the interview that educational deficiencies the teacher experienced in this dimension were arisen from "related to student" (student level).

In accordance with the views of all teachers on the dimension of "related to curriculum/time" (T1), "related to school/ lack of material for the experiment," "related to student/student level," and "related to curriculum/time" (T2), "related to school/lack of material" (T3), and "related to student/student level" (T4) were obtained in general.

\subsection{The Findings Related to the Dimension of Material}

In this section of the findings, alignment levels teachers were not considered because having no expression on this dimension in MoNE curriculum and annual plan in units that all secondary education teachers benefited within the framework of "material" dimension for all secondary schools included into the research. Accordingly, the number and varieties of the materials all secondary education teachers used during the process were included in this section, and direct quotations including the interview questions and answers related to this dimension were also presented.

In Table 9, when the materials the teachers in observed secondary education schools used were analyzed, the materials used by the teachers during the educational process were noticed to be course book, supplementary book, poster, flower model, real flower or seed, projection device, study sheets, types of waste materials (for the project), microscope, and smart board. The number materials used by the teacher carrying on his/her duty in Türkiye Petrolleri Secondary Education School with high success level was noticed to be 3 , and these were course book, flower model, and study sheets. The number materials used by the teacher carrying on his/her duty in 50 . Y1l Secondary Education School with medium success level was noticed to be 6 , and these were course book, poster, flower model, project device, study sheets, and types of waste materials necessary for the project. The number materials used by the teacher carrying on his/her duty in TOKI Akşemseddin Secondary Education School with high success level was noticed to be 4 , and these were course book, flower model, study sheets, and microscope. And finally, the teacher of Özel Doruk Secondary Education School used 5 materials including course book, supplementary book, real flower or seed, study sheets and smart board. The expressions of all teachers related to the "interview question" on this dimension were as below.

Table 9. The materials all secondary education school teachers used during the process

\begin{tabular}{|c|c|c|c|c|}
\hline & $\begin{array}{c}\text { Türkiye Petrolleri } \\
\text { Secondary School Teacher }\end{array}$ & $\begin{array}{c}\text { 50. Y1 Secondary } \\
\text { School Teacher }\end{array}$ & $\begin{array}{c}\text { TOKI Akşemseddin } \\
\text { Secondary School Teacher }\end{array}$ & $\begin{array}{c}\text { Özel Doruk Secondary } \\
\text { School Teacher }\end{array}$ \\
\hline Course book & $\checkmark$ & $\checkmark$ & $\checkmark$ & $\checkmark$ \\
\hline Supplementary book & - & - & - & $\checkmark$ \\
\hline Poster & - & $\checkmark$ & $\checkmark$ & - \\
\hline Flower model & - & - & - & $\checkmark$ \\
\hline Real flower or seed & - & $\checkmark$ & $\checkmark$ & $\checkmark$ \\
\hline Projection device & $\checkmark$ & $\checkmark$ & - & - \\
\hline Study sheets & - & $\checkmark$ & $\checkmark$ & - \\
\hline (For the project) Types of \\
waste materials
\end{tabular}


Table 10. "Material" dimension interview questions, quotations from the answers, and themes and codes developed for these

\begin{tabular}{|c|c|c|}
\hline Interview Questions for Teachers & Theme/Code & Quotation \\
\hline $\begin{array}{l}\text { Türkiye Petrolleri Secondary Education School: } \\
\text { Course book, study sheets, and flower model were } \\
\text { used as the materials. However, the samples of } \\
\text { living beings possible to be related to the unit } \\
\text { (canary, fungi, bacteria, flower, animal, etc.) could } \\
\text { not be brought to the classroom, no supplementary } \\
\text { book (for explanation) and microscope were used. } \\
\text { Why? }\end{array}$ & $\begin{array}{l}\text { *Related to teacher } \\
\text { /Teacher preference }\end{array}$ & $\begin{array}{l}\text { T1: Samples from the real life can be brought, of course. We also } \\
\text { have a microscope; it can be used. But I can say that I do not even } \\
\text { have the key of the laboratory. I have not used it yet because I } \\
\text { have just started to this school. The source book is possible to be } \\
\text { benefited in an noncompulsory way. It is also possible to find } \\
\text { fungi, it is easy to reach. }\end{array}$ \\
\hline $\begin{array}{l}\text { 50. Y1l Secondary Education School: } \\
\text { As the material, course book, projection, study } \\
\text { sheets, background papers for banner and posters, } \\
\text { recycling boxes, and flower model were used. } \\
\text { However, the samples of living beings (bacteria, } \\
\text { flower, animal, etc.) were not brought to the } \\
\text { classroom. Why? }\end{array}$ & $\begin{array}{l}\text { *Related to other } \\
\text { situations/ } \\
\text { Supplementary books } \\
\text { * Related to teacher } \\
\text { /Teacher preference } \\
\text { *Related to school/ } \\
\text { Lack of material }\end{array}$ & $\begin{array}{l}\text { T2: We did not use the supplementary books they were } \\
\text { prohibited, and we did not use the microscope because it was } \\
\text { broken. We could increase the samples, but the students in other } \\
\text { classrooms I lectured could only bring some types of fungi } \\
\text { (fungus, blastomycete, parasol mushroom) and flowerless plants. } \\
\text { We have a room of equipment-tools, but the required materials } \\
\text { are mostly missing. }\end{array}$ \\
\hline $\begin{array}{l}\text { TOKI Akșemseddin Secondary Education School: } \\
\text { Course books, study sheets, microscope and flower } \\
\text { model were used as the material. However, the } \\
\text { samples of living beings (bacteria, flower, animal, } \\
\text { etc.) were not brought to the classroom; the } \\
\text { supplementary book was not used (for explaining). } \\
\text { Why? }\end{array}$ & $\begin{array}{l}\text { * Related to teacher } \\
\text { /Teacher preference } \\
\text { (the expressions such } \\
\text { as "I considered as } \\
\text { necessary" and "I did } \\
\text { not think") } \\
\text { * Related to other } \\
\text { situations /Parents }\end{array}$ & $\begin{array}{l}\text { T3: We did not bring to the classroom, but I could take students } \\
\text { out of the class and show them. You can think that I avoided, but I } \\
\text { thought that there was a camera in the classroom and you were in } \\
\text { the classroom. I thought it was necessary to spend the process in } \\
\text { the classroom. I could bring animals or the students could be } \\
\text { asked to bring if they had one at home, but I could not think so. } \\
\text { When the supplementary book was considered, Ministry of } \\
\text { National Education has never mentioned us these are } \\
\text { prohibited, there is no such obligation. I request book in order } \\
\text { to provide students understand the subjects better, but only two } \\
\text { or three of the parents think so. Namely, the basic reason is } \\
\text { parents' not thinking so. }\end{array}$ \\
\hline $\begin{array}{l}\text { Özel Doruk Secondary Education School: } \\
\text { Course book, supplementary question book, study } \\
\text { sheets, smart board, flower samples and bean, } \\
\text { chickpea and lentil grains were used as the } \\
\text { materials. However, samples possible to be coherent } \\
\text { with the unit and included in the course book (fungi, } \\
\text { bacteria, animal, etc.) were not brought to the } \\
\text { classroom, and the microscope was not used. Why? }\end{array}$ & $\begin{array}{l}\text { * Related to teacher } \\
\text { /Teacher preference } \\
\text { *Related to curriculum/ } \\
\text { Time }\end{array}$ & $\begin{array}{l}\text { T4: Because these materials were performed to the students in } \\
\text { the same group in previous years and I experienced time problem } \\
\text { in the curriculum of this year, I did not include. }\end{array}$ \\
\hline
\end{tabular}

In the answer of $\mathrm{T} 1$ teacher, the teacher was noticed not to include living samples within the framework of material dimension, reaching to samples mentioned in the course book as considered to be appropriate with the unit was easy, but these materials were not used for any reasons, s/he had no key of the laboratory because s/he has just started to work at school for using the microscope, and the supplementary book was not included into the process because it could also be used out of classroom. However, it was noticed that this was not arisen from teacher's making effort to be in alignment with MoNE curriculum and annual plan in units (because these materials were not included in curriculum materials) in terms of "material" dimension, because the teacher was determined to use the materials not included in the curriculum and annual plan during the process as could be seen in the Table. In conclusion, as result of the observation, there was "no alignment" between the curriculums in dimension of "material" for the teacher carrying on his/her duty in Türkiye Petrolleri Secondary Education School, and it was noticed as result of the interview that educational deficiencies the teacher experienced in this dimension were arisen from the reason as "related to teacher" (teacher preference).
In the answer given by $\mathrm{T} 2$ teacher, s/he was noticed to mention that the students in the other classrooms apart from the observed one brought only fungi and flowerless plant samples, however the number of these samples should be increased, these should be presented in all classrooms, and supplementary books were not included because these were prohibited, and the microscope was not included because the material was broken. However, it was noticed that this was not arisen from teacher's making effort to be in alignment with MoNE curriculum and annual plan in units (because these materials were not included in curriculum materials) in terms of "material" dimension, because the teacher was determined to use the materials not included in the curriculum and annual plan during the process as could be seen in the Table. In conclusion, as result of the observation, there was "no alignment" between the curriculums in dimension of "material" for the teacher carrying on his/her duty in 50. Y1l Secondary Education School, and it was noticed as result of the interview that educational deficiencies the teacher experienced in this dimension were arisen from the reasons as "related to other situations" (supplementary books), "related to teacher" (teacher preference), and "related to school" (lack of 
material).

In the answer of T3 teacher, it was mentioned that the teacher did not use animal or plant samples within the framework of material dimension, it was possible to bring the samples into the classroom, but there was a different environment due to the camera in the classroom, $\mathrm{s} / \mathrm{he}$ also considered that the process should be within classroom environment; and the supplementary books were not included because the parent did not buy them. Moreover, the teacher was also noticed not to think bringing animals to the classroom. S/he expressed that this was not arisen from MoNE's suggesting not obliging students for supplementary books but from the indifference of parents towards buying supplementary books. As in Türkiye Petrolleri and 50 Y1l Secondary Education Schools, it was noticed that this was not arisen from teacher's making effort to be in alignment with MoNE curriculum and annual plan in units (because these materials were not included in curriculum materials) in terms of "material" dimension, because the teacher was determined to use the materials not included in the curriculum and annual plan during the process as could be seen in the Table. In conclusion, as result of the observation, there was "no alignment" between the curriculums in dimension of "material" for the teacher carrying on his/her duty in TOKI Akşemseddin Secondary Education School, and it was noticed as result of the interview that educational deficiencies the teacher experienced in this dimension were arisen from the reasons as "related to teacher" (teacher preference) (I thought as it was necessary/I could not think, etc.), and "related to other situations" (parents).

In the answer given by T4, it was noticed that the teacher did not use samples and microscope within the framework of material dimension, s/he performed these materials mentioned in the course book to the same students in previous years, and these were also not performed due to the lack of time. However, as in other observed three secondary education schools, it was determined that this was not arisen from teacher's making effort to be in alignment with MoNE curriculum and annual plan in units (because these materials were not included in curriculum materials) in terms of "material" dimension, because the teacher was determined to use the materials not included in the curriculum and annual plan during the process as could be seen in the Table. Moreover, when the expression of teacher for the interview question was analyzed, the teacher could be understood to use other materials that were not used if no time problem was experienced. In conclusion, as result of the observation, there was "no alignment" between the curriculums in dimension of "material" for the teacher carrying on his/her duty in Özel Doruk Secondary Education School, and it was noticed as result of the interview that educational deficiencies the teacher experienced in this dimension were arisen from the reasons as "related to teacher" (teacher preference), and "related to curriculum" (time).

In accordance with the views of all teachers on the dimension of "material," the themes and codes of "related to teacher/teacher preference" (T1), "related to other situations/supplementary books," "related to teacher/teacher preference," "related to school/lack of material," "related to other situations/parents" (T3), "related to teacher/teacher preference (I considered as necessary-I could not think so)," and "related to teacher/teacher preference" and "related to curriculum/time" (T4) were obtained in general.

\subsection{The Findings Related to the Dimensions of Measurement-assessment}

In terms of this dimension, no details were included in MoNE curriculum. Accordingly, alignment levels of annual plan in units and teacher implementation processes were analyzed for 50 Yil Secondary Education School, TOKI Akşemseddin Secondary Education School and Özel Doruk Secondary Education School according to observation results in this section of the findings. The situation was different in terms of Türkiye Petrolleri Secondary Education School. In this secondary education school, alignment level of the teacher was not regarded in this dimension because there was no expression related to the dimension of measurement and assessment in the annual plan in units and curriculum. For that reason, measurement and assessment techniques used by all secondary education school teachers during the observation process were discussed in a Table, the techniques (in number and variety) included by the Türkiye Petrolleri Secondary School teacher in terms of assessment and measurement dimension was compared with other secondary education schools. Moreover, direct quotations related to interview questions and answers of all teachers on this dimension were presented below. 
Table 11. Measurement and assessment techniques used by all secondary education school teachers during the observation

\begin{tabular}{|c|c|c|c|c|}
\hline & $\begin{array}{l}\text { Türkiye Petrolleri } \\
\text { Secondary School }\end{array}$ & $\begin{array}{l}\text { 50. Yil Secondary } \\
\text { School }\end{array}$ & $\begin{array}{l}\text { TOKİ Akşemseddin } \\
\text { Secondary School }\end{array}$ & $\begin{array}{c}\text { Özel Doruk } \\
\text { Secondary School }\end{array}$ \\
\hline Concept map technique & $\checkmark$ & $\checkmark$ & $\checkmark$ & $\checkmark$ \\
\hline Mind map technique & - & - & - & - \\
\hline Structured grid technique & - & - & - & _- \\
\hline Diagnostic tree technique & $\checkmark$ & $\checkmark$ & $\checkmark$ & $\checkmark$ \\
\hline Six-hat technique & _- & _- & $1+$ & _- \\
\hline Jigsaw technique was used. & $\checkmark$ & $\checkmark$ & $\checkmark$ & $\checkmark$ \\
\hline Multiple choice test technique was used. & $\checkmark$ & $\checkmark$ & $\checkmark$ & $\checkmark$ \\
\hline Open/close ended question technique was used. & $\checkmark$ & $\checkmark$ & $\checkmark$ & $\checkmark$ \\
\hline Fill-in-the-gaps technique was used. & $\checkmark$ & $\checkmark$ & $\checkmark$ & $\checkmark$ \\
\hline True-false technique was used. & $\checkmark$ & $\checkmark$ & $\checkmark$ & $\checkmark$ \\
\hline Matching technique was used. & $\checkmark$ & $\checkmark$ & $\checkmark$ & $\checkmark$ \\
\hline Two-stage test technique was used. & $\checkmark$ & $\checkmark$ & $\checkmark$ & $\checkmark$ \\
\hline Project preparation homework & - & $\checkmark$ & - & - \\
\hline Poster preparation homework & _- & $\checkmark$ & _- & - \\
\hline $\begin{array}{l}\text { Activity homework (bean, chickpea } \\
\text { germination) }\end{array}$ & - & - & - & $\checkmark$ \\
\hline Total: & 9 & 11 & 9.5 & 10 \\
\hline
\end{tabular}

In Table 11, when the measurement and assessment techniques used by the teachers carrying on their duties in observed secondary education schools in Science course were analyzed, these techniques were determined to be totally 15 including concept map, mind map, structured grid, diagnostic tree, six-map, jigsaw, multiple-choice test, open/close ended question, fill-in-the-gaps, true-false, matching, two-stage test, project preparation homework, poster preparation homework, and activity homework. Nine techniques used by Türkiye Petrolleri Secondary Education School teacher with high success level were noticed to be concept map, diagnostic tree, jigsaw, multiple-choice test, open/close ended question, fill-in-the-gaps, true-false, matching, and two-stage test techniques. Eleven techniques used by 50. Y1l Secondary Education School teacher with medium success level were noticed to be concept map, diagnostic tree, jigsaw, multiple-choice test, open/close ended question, fill-in-the-gaps, true-false, matching, and two-stage test, project preparation homework and poster preparation homework. Nine techniques used by TOKI Akşemseddin Secondary Education School teacher with low success level were determined to be concept map, diagnostic tree, six-hat (indicated with /+ and accepted to be semi-plus because this was only assigned as homework and not used in classroom), jigsaw, multiple-choice test, open/close ended question, fill-in-the-gaps, true-false, matching, and two-stage test techniques. Finally, ten techniques used by Özel Doruk Secondary Education School teacher included concept map, diagnostic tree, jigsaw, multiple-choice test, open/close ended question, fill-in-the-gaps, true-false, matching, two-stage test, and activity homework.

In Table 12, alignment was noticed for $1,4,6,7,8,9,10$, 11, and 12 measurement and assessment techniques used by the 50. Y1l Secondary Education School teacher. In conclusion, curriculum alignment of this teacher in terms of measurement and assessment dimension was noticed to be at a medium level with 9 points.

Alignment was determined for $1,4,5,6,7,8,9,10,11$, and 12 measurement and assessment techniques used by the TOKI Akşemseddin Secondary Education School teacher. In conclusion, curriculum alignment of this teacher in terms of measurement and assessment dimension was noticed to be at a medium level with 9.5 points. 
Table12. Measurement and assessment techniques used by the teachers during the observation process

\begin{tabular}{|c|c|c|c|}
\hline & $\begin{array}{c}\text { 50. Y1l } \\
\text { Secondary School }\end{array}$ & $\begin{array}{l}\text { TOKİ Akşemseddin } \\
\text { Secondary School }\end{array}$ & Özel Doruk Secondary School \\
\hline $\begin{array}{l}\text { Measurement and Assessment } 1 . \\
\text { Concept map technique }\end{array}$ & $\begin{array}{c}\text { APiU-TI } \\
(+)\end{array}$ & $\begin{array}{l}\text { APiU-TI } \\
(+)\end{array}$ & $\begin{array}{l}\text { APiU-TI } \\
(+)\end{array}$ \\
\hline $\begin{array}{c}\text { Measurement and Assessment } 2 . \\
\text { Mind map technique }\end{array}$ & $\begin{array}{l}\text { APiU-TI } \\
(-)\end{array}$ & $\begin{array}{l}\text { APiU-TI } \\
(-)\end{array}$ & $\begin{array}{l}\text { APiU-TI } \\
(-)\end{array}$ \\
\hline $\begin{array}{c}\text { Measurement and Assessment } 3 . \\
\text { Structured grid technique }\end{array}$ & $\begin{array}{l}\text { APiU-TI } \\
(-)\end{array}$ & $\begin{array}{l}\text { APiU-TI } \\
(-)\end{array}$ & $\begin{array}{l}\text { APiU-TI } \\
(-)\end{array}$ \\
\hline $\begin{array}{c}\text { Measurement and Assessment } 4 . \\
\text { Diagnostic tree technique }\end{array}$ & $\begin{array}{c}\text { APiU-TI } \\
(+)\end{array}$ & $\begin{array}{c}\text { APiU-TI } \\
(+)\end{array}$ & $\begin{array}{c}\text { APiU-TI } \\
(+)\end{array}$ \\
\hline $\begin{array}{c}\text { Measurement and Assessment } 5 . \\
\text { Six-hat technique }\end{array}$ & $\begin{array}{l}\text { APiU-TI } \\
(-)\end{array}$ & $\begin{array}{l}\text { APiU-TI } \\
(/+)=1 / 2+\end{array}$ & $\begin{array}{l}\text { APiU-TI } \\
(-)\end{array}$ \\
\hline $\begin{array}{l}\text { Measurement and Assessment } 6 . \\
\text { Jigsaw technique }\end{array}$ & $\begin{array}{l}\text { APiU-TI } \\
(+)\end{array}$ & $\begin{array}{c}\text { APiU-TI } \\
(+)\end{array}$ & $\begin{array}{l}\text { APiU-TI } \\
(+)\end{array}$ \\
\hline $\begin{array}{l}\text { Measurement and Assessment } 7 . \\
\text { Multiple-choice test technique }\end{array}$ & $\begin{array}{c}\text { APiU-TI } \\
(+)\end{array}$ & $\begin{array}{c}\text { APiU-TI } \\
(+)\end{array}$ & $\begin{array}{c}\text { APiU-TI } \\
(+)\end{array}$ \\
\hline $\begin{array}{l}\text { Measurement and Assessment } 8 . \\
\text { Open/close ended question techniques }\end{array}$ & $\begin{array}{c}\text { APiU-TI } \\
(+)\end{array}$ & $\begin{array}{c}\text { APiU-TI } \\
(+)\end{array}$ & $\begin{array}{c}\text { APiU-TI } \\
(+)\end{array}$ \\
\hline $\begin{array}{c}\text { Measurement and Assessment } 9 . \\
\text { Fill-in-the-gaps technique }\end{array}$ & $\begin{array}{c}\text { APiU-TI } \\
(+)\end{array}$ & $\begin{array}{c}\text { APiU-TI } \\
(+)\end{array}$ & $\begin{array}{c}\text { APiU-TI } \\
(+)\end{array}$ \\
\hline $\begin{array}{c}\text { Measurement and Assessment } 10 . \\
\text { True-false technique }\end{array}$ & $\begin{array}{l}\text { APiU-TI } \\
(+)\end{array}$ & $\begin{array}{c}\text { APiU-TI } \\
(+)\end{array}$ & $\begin{array}{l}\text { APiU-TI } \\
(+)\end{array}$ \\
\hline $\begin{array}{l}\text { Measurement and Assessment } 11 . \\
\text { Matching technique }\end{array}$ & $\begin{array}{l}\text { APiU-TI } \\
(+)\end{array}$ & $\begin{array}{c}\text { APiU-TI } \\
(+)\end{array}$ & $\begin{array}{l}\text { APiU-TI } \\
(+)\end{array}$ \\
\hline $\begin{array}{l}\text { Measurement and Assessment } 12 . \\
\text { Two-stage test technique }\end{array}$ & $\begin{array}{c}\text { APiU-TI } \\
(+)\end{array}$ & $\begin{array}{c}\text { APiU-TI } \\
(+)\end{array}$ & $\begin{array}{c}\text { APiU-TI } \\
(+)\end{array}$ \\
\hline $\begin{array}{l}\text { Measurement and Assessment } 13 . \\
\text { Project preparation homework was } \\
\text { assigned. }\end{array}$ & $\begin{array}{l}\text { APiU-TI } \\
\quad(-)\end{array}$ & $\begin{array}{l}\text { APiU-TI } \\
\mathbf{0}\end{array}$ & $\begin{array}{l}\text { APiU-TI } \\
\mathbf{0}\end{array}$ \\
\hline $\begin{array}{l}\text { Measurement and Assessment } 14 . \\
\text { Poster preparation homework was } \\
\text { assigned. }\end{array}$ & $\begin{array}{l}\text { APiU-TI } \\
(-)\end{array}$ & $\begin{array}{l}\text { APiU-TI } \\
\quad 0\end{array}$ & $\begin{array}{l}\text { APiU-TI } \\
\quad 0\end{array}$ \\
\hline $\begin{array}{l}\text { Measurement and Assessment } 15 . \\
\text { Activity homework (bean, chickpea } \\
\text { germination) }\end{array}$ & $\begin{array}{l}\text { APiU-TI } \\
\mathbf{0}\end{array}$ & $\begin{array}{l}\text { APiU-TI } \\
\mathbf{0}\end{array}$ & $\begin{array}{l}\text { APiU-TI } \\
(-)\end{array}$ \\
\hline Average & $\begin{array}{l}\text { (Measurement and assessment } 1, \\
4,6,7,8,9,10,11,12):=(9+)= \\
9 \text { point }(\text { Medium level) }\end{array}$ & $\begin{array}{c}\text { (Measurement and } \\
\text { assessment } 1,4,5(1 / 2+), 6 \\
7,8,9,10,11,12)=(\mathbf{9 . 5}+) \\
=9.5 \text { point }(\text { Medium level) }\end{array}$ & $\begin{array}{c}\text { (Measurement and } \\
\text { assessment } 1,4,6,7,8,9,10, \\
11,12)=\mathbf{9 +}=\mathbf{9} \text { point } \\
\text { (Medium level) }\end{array}$ \\
\hline \multicolumn{4}{|c|}{$\begin{array}{l}\text { Measurement and Assessment Dimension General Curriculum Alignment Level: “0 (Türkiye Petrolleri Secondary Education School)+9+9.5+9"/4= } \\
\text { 6.9 point (low level) }\end{array}$} \\
\hline
\end{tabular}

Alignment was determined for $1,4,6,7,8,9,10$, and 11 measurement and assessment techniques used by the Özel Doruk Secondary Education School teacher. In conclusion, curriculum alignment of this teacher in terms of measurement and assessment dimension was noticed to be at a medium level with 9 points. General curriculum alignment level of the teachers in terms of measurement and assessment dimension was found to be at a low level with 6.9 points. The expressions of all teachers related to the "interview question" on this dimension were as below in the table.

In Table 13, in the answer of $\mathrm{T} 1$, it was noticed that the teacher did not use the techniques such as mind map, two-stage test, six-hat thinking, project preparation, poster preparation, and activity homework that were considered to be appropriate within the framework of measurement and assessment dimension because $\mathrm{s} / \mathrm{he}$ could not think performing, and the camera had also a negative effect on not performing. Considering this expression of the teacher, it was understood that $\mathrm{s} /$ he did not include measurement and assessment methods/techniques that were appropriate with the unit in general during the educational process. Namely, the teacher mentioned that s/he could use the other techniques that were not used during the observed courses for this unit if $\mathrm{s} / \mathrm{he}$ did not forget. There were no expressions related to measurement and assessment in the curriculum and annual plan in units prepared by MoNE. In this sense, no curriculum alignment level was regarded for this school. In conclusion, as result of the observation, there was "no alignment" between the curriculums in dimension of "measurement and assessment" for the teacher carrying on his/her duty in Türkiye Petrolleri Secondary Education School, and it was noticed as result of the interview that the teacher's not performing some measurement and assessment techniques was arisen from a reason "related to teacher (to forget)." 
Table 13. "Measurement and assessment" dimension interview questions, quotations from the answers, and themes and codes developed for these

\begin{tabular}{|c|c|c|}
\hline Interview Questions for Teachers & Theme/Code & Quotation \\
\hline $\begin{array}{l}\text { Türkiye Petrolleri Secondary Education School: } \\
\text { Question types on study sheets we took from a different } \\
\text { source were benefited for measurement and assessment. } \\
\text { However, different techniques such as mind map, two-stage } \\
\text { test, six-hat thinking, project preparation, poster preparation } \\
\text { and activity possible to be relevant with the unit were not } \\
\text { included. Why? }\end{array}$ & $\begin{array}{l}\text { *Related to teacher/ } \\
\text { To forget }\end{array}$ & $\begin{array}{l}\text { T1: No, I used, I could not think. The camera had } \\
\text { negative effect on me, namely I did not feel myself at } \\
\text { ease. }\end{array}$ \\
\hline $\begin{array}{l}\text { 50. Y1l Secondary Education School: } \\
\text { For measurement and assessment, the methods and } \\
\text { techniques mentioned in the annual plan in units and study } \\
\text { sheets we took from a different source were benefited. } \\
\text { However, different techniques mind maps, structured grid, } \\
\text { and six-hat techniques possible to be aligned with the unit } \\
\text { were not included. Why? }\end{array}$ & $\begin{array}{l}* \text { Related to teacher / } \\
\text { Teacher preference }\end{array}$ & $\begin{array}{l}\text { T2: I had no activity or source appropriate for mind } \\
\text { map, structured grid and six-hat technique. }\end{array}$ \\
\hline $\begin{array}{l}\text { TOKİ Akșemseddin Secondary Education School: } \\
\text { For measurement and assessment, the annual plan in units } \\
\text { was benefited. However, different techniques such as mind } \\
\text { map and structured grid mentioned in the annual plan in } \\
\text { units were not included. Why? }\end{array}$ & $\begin{array}{l}\text { *Related to student/ } \\
\text { Success level of students } \\
\text { *Related to curriculum/ } \\
\text { Time } \\
\text { * Related to teacher /I } \\
\text { heard for the first time (I } \\
\text { don't know), maybe it is } \\
\text { what I perform (I don't } \\
\text { know). }\end{array}$ & $\begin{array}{l}\text { T3: The success levels of the students are low, the time } \\
\text { can be problem. Mind map technique was not } \\
\text { performed visually; I thought they could visualize on } \\
\text { their mind. I heard mind map for the first time. } \\
\text { Structured grid and mind map are possible to be } \\
\text { techniques we do not know, but we possibly perform; I } \\
\text { think we do not perform because we do not know its } \\
\text { definition. }\end{array}$ \\
\hline $\begin{array}{l}\text { Özel Doruk Secondary Education School: } \\
\text { For measurement and assessment, the methods and } \\
\text { techniques mentioned in the annual plan in units and study } \\
\text { sheets we took from a different source and activity } \\
\text { homework were benefited. However, techniques such as } \\
\text { mind map, structured grid and six-hat mentioned in the } \\
\text { annual plan in units were not included. Why? }\end{array}$ & $\begin{array}{l}\text { * Related to teacher / } \\
\text { Teacher preference } \\
\text { *Related to curriculum/ } \\
\text { Time }\end{array}$ & $\begin{array}{l}\text { T4: I did not omit these assessment techniques because } \\
\text { I thought I could include during the process; in fact, I } \\
\text { did not include because I had no sufficient time. }\end{array}$ \\
\hline
\end{tabular}

In the answer of $\mathrm{T} 2$, the teacher was noticed not to have an appropriate activity or source for mind maps, structured grid, and six-hat techniques s/he did not use within the framework of measurement and assessment dimension. This expression of the teacher indicated that $\mathrm{s} / \mathrm{he}$ had a high level of alignment, event not completely, with the annual plan in units through not with the curriculum prepared by MoNE in terms of measurement and assessment dimension. Because there was no expression related to measurement and assessment in the curriculum prepared by MoNE. In conclusion, as result of the observation, there was "a medium level alignment" between the curriculums in dimension of "measurement and assessment" for the teacher carrying on his/her duty in 50. Y1l Secondary Education School; and it was noticed as result of the interview that educational deficiencies the teacher experienced in this dimension were arisen from the reason as "related to teacher" (teacher preference).

In the answer of T3, the teacher was determined not to be sure on using or not using mind maps and structured grid techniques because of not knowing the definitions of these. Moreover, the teacher was also noticed to consider the appropriateness of measurement and assessment methods/techniques for students' success level, and experience time problem. This expression of the teacher (such as T2 observed in 50 Yil Secondary Education School) indicated that $\mathrm{s} / \mathrm{he}$ was aligned, though not completely, with the annual plan in units despite not being with the curriculum prepared by MoNE in terms of measurement and assessment. Because there was no expression related to measurement and assessment in the curriculum prepared by MoNE. In conclusion, as result of the observation, there was "a medium level alignment" between the curriculums in dimension of "measurement and assessment" for the teacher carrying on his/her duty in TOKI Akşemseddin Secondary Education School; and it was noticed as result of the interview that educational deficiencies the teacher experienced in this dimension were arisen from the reasons as "related to student" (success level of the students), "related to curriculum (time)" and "related to teacher (I heard for the first time "I don't know" / maybe it is what I perform "I don't know").

In the answer of T4, the teacher was noticed not to use teaching methods/techniques within the framework of measurement and assessment dimension, s/he planned to include mind maps, structured grid and six-map techniques mentioned in the annual plan as being considered to be appropriate with the unit during the process, but could not due to lack of time. This expression of the teacher (such as T2 observed in 50 Y1l Secondary Education School and T3 observed in TOKI Akşemseddin Secondary Education School) indicated that $\mathrm{s} / \mathrm{he}$ was aligned, though not completely, with the annual plan in units despite not being with the curriculum prepared by MoNE in terms of 
measurement and assessment. Because there was no expression related to measurement and assessment in the curriculum prepared by MoNE. In conclusion, as result of the observation, there was "a medium level alignment" between the curriculums in dimension of "measurement and assessment" for the teacher carrying on his/her duty in Özel Doruk Secondary Education School; and it was noticed as result of the interview that educational deficiencies the teacher experienced in this dimension were arisen from the reasons as "related to teacher (teacher preference) and "related to curriculum" (time).

In accordance with the views of all teachers on the dimension of "measurement and assessment," the themes and codes of "related to teacher/to forget" (T1), "related to teacher/teacher preference," (T2), "related to student/success levels of the students," "related to curriculum/time," and "related to teacher/I heard for the first time (I don't know)" (T3), and "related to teacher/teacher preference "related to curriculum/time" (T4) were obtained in general.

Finally, in this section, a Table as a summary of all findings was prepared, and alignment levels of all secondary education schools within the scope of curriculum dimensions were described.

In Table 14, when Science curriculum alignment of the teachers carrying on their duties in observed schools were analyzed, alignments of the teachers in all secondary education schools in "acquisition" dimension were noticed to be at medium level. In terms of the "content dimension, all teachers were determined to have the same curriculum alignment level, and this level was very high. Because "teaching methods and techniques" and "material" dimensions were both not included in all annual plans in units and MoNE curriculum, no alignment level was regarded in these dimensions, and accordingly, indicated with the symbol of "_" in the Table. In terms of "activity" dimension, curriculum alignment of the teacher carrying on his/her duty in Türkiye Petrolleri Secondary Education School with high success level was noticed to be non-aligned, and the reasons for this were MoNE curriculum's including no activity, teacher's including 3 activities in the annual plan in units and not using any of the activities despite including. When other secondary education schools were analyzed in terms of "activity" dimension, curriculum alignment of 50 Y1l Secondary Education Teacher with medium success level was at a low level, and curriculum alignments of the TOKI Akșemseddin and Özel Doruk Secondary Education School teachers with low level of success were at a very low level. Finally, it was also noticed in the Table that, no curriculum alignment was regarded for the teacher carrying on his/her duty in Türkiye Petrolleri Secondary Education School, and indicated with the symbol of "-;" and the reason for this was this dimension's not being included in both MoNE curriculum and the annual plan in units benefited by the teacher. In the Table, it was also determined that the curriculum alignments for the teachers of 50. Y11 Secondary Education School, TOKİ Akşemseddin Secondary Education School and Özel Doruk Secondary Education School in terms of "measurement and assessment" dimension were at a medium level.

\section{Discussion and Conclusions}

During the observations, curriculum alignments of the teachers were analyzed, and it was determined when all dimensions of the curriculum were discussed that there was no high alignment in general, curriculum alignment of all teachers were only at a very high level in "content" dimension, and when considered in details, curriculum alignments of teachers could not be regarded in more than one dimension because there was no expression related to the relevant dimensions in the annual plan in units.

Table 14. Curriculum alignment levels of all secondary education schools

\begin{tabular}{|c|c|c|c|c|}
\hline & $\begin{array}{c}\text { Türkiye Petrolleri } \\
\text { Secondary Education } \\
\text { School }\end{array}$ & $\begin{array}{c}\text { So. Yll } \\
\text { Secondary Education } \\
\text { School }\end{array}$ & $\begin{array}{c}\text { TOKI Akssemseddin } \\
\text { Secondary Education } \\
\text { School }\end{array}$ & $\begin{array}{c}\text { Ozzel Doruk Secondary } \\
\text { Education School }\end{array}$ \\
\hline Acquisition & Medium & Medium & Medium & Medium \\
\hline Content & Very high & Very high & Very high & Very high \\
\hline $\begin{array}{c}\text { Teaching methods and } \\
\text { techniques }\end{array}$ & - & - & - & Very low \\
\hline Activity & Non-aligned & Low & Very low & - \\
\hline Material & - & - & - & Medium \\
\hline $\begin{array}{c}\text { Measurement and } \\
\text { assessment }\end{array}$ & - & Medium & & Medium \\
\hline
\end{tabular}


According to the observation results, curriculum alignment of the teacher in Türkiye Petrolleri Secondary Education School with high success level was at a medium level in acquisition" dimension, was at a very high level in "content" dimension, and was non-aligned in activity dimension. In terms of the "teaching methods and techniques" and "measurement and assessment" dimensions, no alignment was regarded; and it was concluded that the number of materials and methods and techniques the teachers benefited for these dimensions were limited in number. This could be expressed through the fact that curriculum alignment of the teacher was not at a high level when considered in general. During the interview related to this result, the teacher was noticed to express that some factors related to teacher and curriculum were efficient upon "acquisition" dimension's being at a medium level instead of high. Upon this, LeMarca, Redfield, Winter and Despriet (2000:24; Cited in: Hill, [20]) emphasized the importance of acquisitions dimension as a concrete indicator of the standards expressed in the expression of "the level of the results appeared by assessments providing accurate information on student performance depending upon desired level of academic standards" in their study while defining the alignment. For that reason, it should be emphasized that it is necessary to regard acquisition dimension as essential and important like all other dimensions of the curriculum for fulfilling completely. Teacher's not preparing the annual plan in unit as an important part of the curriculum process by the self in accordance with the educational conditions and his/her not adhering to the plan during the process could be mentioned as the individual preference of the teacher. The reason for the presence of such kind of non-alignment on curriculum alignment was arisen from teachers completely, not from different factors. Upon this, the expression of Şenel [21] in his study mentioning that "the way teachers followed in education were different according to their own preferences" supported this. In his master degree dissertation, Rençber [22] concluded that teachers were unwilling and prejudiced against the curriculum and implementations, they did not adopt the purpose and vision of the curriculum, and they had the willing for maintaining the traditional implementations. As could be understood here, teachers' individual preferences, requests, prejudices and their adaption into curriculum affected their administering the curriculum. Furthermore, it was also noticed that no curriculum alignment was regarded in activity dimension in which curriculum alignment level of the teacher was non-aligned, and some factors related to teacher were efficient on material and measurement and assessment dimensions.

Curriculum alignment of the teacher in 50. Yil Secondary Education School with medium success level in TEOG exam was noticed to be medium in acquisition dimension, very high in content dimension, low in activity dimension, and medium in measurement and assessment dimension. In educational status and material dimension, no alignment was regarded, and it was concluded that the methods and techniques and the materials benefited for this dimension were limited in number. As could be seen here, curriculum alignment of the teacher could be expressed as not high when considered in general. During the interview related to this result, the teacher was noticed to express on his/her medium level alignment in acquisition dimension instead of high that some negative factors related to the curriculum and students were efficient on this. The teacher also mentioned that the contents' not being included into annual plan in units was arisen from its being prepared by the group teachers of another school, and in fact, it should be prepared considering the current conditions of the school by the teacher's self. Similarly, 2014-2015 Academic Year Ankara Province Group Teachers' Report [23], the expressions of "The plan's being used as ready is very inaccurate and this killed creativity," and "teachers should prepare their own activities on their own" were noticed to be included within the framework of plans and course preparation problems. The teachers were determined to indicate that some negative factors related to school and other situations were efficient in teaching methods and techniques dimension, factors related to school, student and curriculum were efficient in activity dimension, factors related to school, teacher and curriculum in material dimension, and factors related to teacher were efficient in measurement and assessment dimension.

Curriculum alignment of the teacher carrying on his/her duty in TOKI Akşemseddin Secondary Education School with the lowest success level in TEOG exam was concluded to be medium in acquisition dimension, very high in content dimension, and medium in measurement and assessment level. In educational status and material dimensions, no alignment was regarded, and it was concluded that the methods and techniques and the materials benefited for this dimension were limited in number. This could be interpreted in a way that the teacher had no curriculum alignment in general, and his/her curriculum alignment level was not high. During the interview related to this result, the teacher was noticed to express medium level alignment as being arisen from postponing one of the acquisitions consciously. Alignment in content dimension was found to be very high. During the interview related to this result, it was mentioned that the teacher did not like adhering to the plan, s/he lectured what should be lectured to the students, s/he considered that the plan was nonfunctional, and it was not important even the contents were written in the plan. In return for this expression of the teacher, Taşdemir and Taşdemir [24] explained that teachers' fulfilling the teaching activities successfully was directly correlated with their competence of using and planning annual plan in units, course plan and the teaching activities such as sightseeing, observation and experiment in accordance with the principles. In the dimension of teaching methods and techniques, it was concluded that the factors 
related to curriculum, student, school and other situations were efficient upon teacher's curriculum alignment's being non-aligned. In activity dimension, the reasons for the very low level of teacher's curriculum alignment was reported as related to school, teacher, and other factors. The reasons for the medium level curriculum alignment were determined to be caused by the factors related to curriculum, student and teacher.

Curriculum alignment of the teacher carrying on his/her duty in Özel Doruk Secondary Education School with the high success level in TEOG exam was concluded to be medium in acquisition dimension, very high in content dimension, very low in activity dimension, and medium in measurement and assessment level. In educational status and material dimensions, no alignment was regarded, and it was concluded that the methods and techniques and the materials benefited for this dimension were limited in number. This could be interpreted in a way that the teacher did not fulfill curriculum alignment in general, and curriculum alignment level was not high. During the interview related to this result, it was specified that the factor related to teacher was efficient upon teacher's medium level curriculum alignment, namely project activity as one of the acquisitions was not performed consciously, and this indirectly depended upon time problem caused by the curriculum. On time problem, Caner and Tertemiz [25] reported as similar to our study that course hours in the syllabus were not adequate for performing the curriculum, and more time was needed in order to perform the activities. In another study, similarly, it was stated that course hours for administering the curriculum were inadequate [26]. The teacher view related to high level alignment in content dimension was related to its being arisen from the teacher's following the curriculum through his/her knowledge and experience. This could be interpreted in a way that the teacher considered him/her competent on knowledge related to issues on his/her profession, and had high level self-confidence. However, teacher's expression related to following the curriculum permanently and his/her having no high curriculum alignment as result of the observation seemed conflicting. Regarding no alignment in teaching methods and techniques and material dimensions was arisen from these dimensions' not being included into curriculum and annual plan in units. Although this private school was expected to have environments available more for several teaching methods and techniques and include classrooms with less number of students, the teacher was noticed to include limited numbers of teaching methods and techniques. The view teacher mentioned after the observation was that $\mathrm{s} /$ he considered lecturing the unit better in that way; and s/he performed these methods and techniques in previous units. This expression could be interpreted as teacher's being self-ordained. The reason for teacher's performing few numbers of activities was noticed to be indicated as lack of materials. This could be considered as school management's not providing the necessary equipment in terms of materials or teachers' having no requests on this. The expression of this teacher clarifying that some activities could not be performed due to missing materials was very similar to the expression of one of the teachers in the study carried out by Özdemir [27] mentioning that "We perform the activities; however, some of the activities could not be performed because of material deficiency and some others because of crowded classroom environments. Having no sufficient supplementary books, equipment and necessary materials for the activities negatively affect the full implementation of the curriculum," and these tow results were possible to be mentioned as supporting each other. Moreover, the teacher was also determined to include all materials for the dimension of material previously, and s/he only used some materials in this unit due to lack of time. Curriculum alignment's being at a low level in measurement and assessment dimension was mentioned to be arisen from the time problem.

As different from the other three secondary education schools, whereas the situation was expected to be different because of parents' being financially stronger in terms of their socio-economic conditions, the school's having more technologically supported opportunities, and having less number of students in classrooms in this private secondary education school, the result was different. Therefore, it was remarkable for the teacher carrying on his/her duty in this school to have no high level curriculum alignment as the others carrying on their duties in other three secondary education schools. It could be possible to mention the school management and teacher factors as responsible for this. In thesis study of Acar [4] related to evaluation of new elementary education curriculums according to the views of teachers, it was reported that teachers' having behavioral deficiencies related to teaching complicated the curriculums to be administered. When the other results related to the process section of education were analyzed in the study, the reason for the teachers for not supplying the equipment necessary for education were mentioned as their not having these materials, the school's not having these materials, teachers' not knowing how to use these or not being accustomed to use these. In terms of assessment dimension, teachers' incompetence towards the assessment dimension of the curriculum was reported. Upon this, Warring [28] explained that an assessment in accordance with the curriculum could be beneficial mentioning that "Well-designed assessments that are formative as well as summative, are aligned with curricula, take into account student and cultural variables, are focused on higher-order skills, and with timely turnaround of results can be useful tools to support effective teaching in every subject and grade." Coşkun [2] expressed in his research on Turkish curriculum that the in-service training related to the curriculum were inadequate for teachers, they sometimes had material deficiency, and therefore experienced problems in administering the curriculum.

In conclusion, this study indicated that the teachers did 
not adhere to the original form of the curriculum during the teaching process, and they administered differently. Another thought-provoking situation on this was none of the teachers' not regarding curriculum alignment despite carrying on their duties in schools with different success levels.

\section{REFERENCES}

[1] Öztürk, E. (2003). An Assessment of High School Biology Curriculum Implementation. (Unpublished doctoral dissertation). Middle East Technical University/Graduate School of Social Sciences. Ankara. http:// tez2.yok.gov.tr/ (12.02.2015)

[2] Coşkun, E. (2005). İlköğretim dördüncü ve beşinci sinif öğretmen ve öğrencilerinin yeni türkçe dersi öğretim programi'yla ilgili görüşleri üzerine nitel bir araştirma, Kuram ve Uygulamada Eğitim Bilimleri, 2 (5), 421-476.

[3] Coşkun, A. (2007). İlköğretim 4. ve 5. Sınıf Sosyal Bilgiler Programı Hakkında Öğretmen Görüşlerine İlişkin Nitel Bir Çalışma, (Ankara İli Örneği). (Yayımlanmamış Yüksek Lisans Tezi). Başkent Üniversitesi Eğitim Bilimleri Enstitüsü, Ankara.

[4] Acar, H. (2007). Yeni İlköğretim Programlarının Öğretmen Görüşlerine Dayalı Olarak Değerlendirilmesi (Yayımlanmamış Doktora Tezi). Eskişehir Osmangazi Üniversitesi, Sosyal Bilimler Enstitüsü, Eskişehir.

[5] Tekbıyık, A. ve Akdeniz, A. R. (2008). İlköğretim Fen ve Teknoloji dersi öğretim programini kabullenmeye ve uygulamaya yönelik öğretmen görüşleri. Necatibey Eğitim Fakültesi Elektronik Fen ve Matematik Eğitimi Dergisi (EFMED), Cilt 2, Sayı 2, Aralık, 23-37.

[6] Çatak, K. (2008). 6. Sınıf Yeni Sosyal Bilgiler Öğretimi Programındaki Öğretme-Öğrenme Süreçlerine Yönelik Öğretmen Görüşleri (Muğla İli Örneği). (Yayımlanmamış Yüksek Lisans Tezi), Muğla Üniversitesi Sosyal Bilimler Enstitüsü, Eğitim Bilimleri Anabilim Dalı, Muğla.

[7] Fettahoğlu, B. (2011). 7. Sınıf Sosyal Bilgiler Öğretim Programının Öğretmen Görüşlerine Göre Değerlendirilmesi-Nitel Bir Çalışma (Gümüşhane İli Örneği). (Yayımlanmamış Yüksek Lisans Tezi). Erzincan Üniversitesi Sosyal Bilimler Enstitüsü, Erzincan, 81-85.

[8] Aykaç, N. \& Ulubey, Ö. (2012). Öğretmen adaylarinin ilköğretim programının uygulanma düzeyine ilişkin görüşleri. Ankara Üniversitesi Eğitim Bilimleri Fakültesi Dergisi, 45(1):63-82.

[9] Scott, R. O. (1983). Curriculum alignment as a model for school improvement. (ERIC Document Reproduction Service No. ED 252 508)

[10] Burti Jr., N. (2010). Curricula Alignment and Its Impact on End of Course Assessment Scores. (Unpublished doctoral dissertation). University of Wilmington/Faculty of University of Wilmington in Innovation and Leadership, Wilmington.

[11] Blank, R. K., Porter, A., \& Smithson, J. (2001). New tools for analyzing teaching, curriculum, and standards in mathematics
\& science: Results from survey of enacted curriculum final report. Washington, DC: Council of Chief State School Officers.

http://www.eric.ed.gov/ERICDocs/data/ericdocs2sq1/content_ storage_01/0000019b/80/19/5d/9a.pdf

[12] Bhola, D. S., Impara, J. C. \& Buckendahl, C. W. (2003). Aligning tests with states' content standards: methods and issues. Educational Measurement: Issues and Practice, 22(3): 21-29.

[13] Porter, A. C., Smithson, J., Blank, R. \& Zeidner, T. (2007). Alignment as a teacher variable. Applied Measurement in Education, 20(1), 27-51.

[14] Martone, A., \& Sireci, S. G. (2009). Evaluating alignment between curriculum, assessment and instruction. Review of Educational Research, 79(3), 1-76.

[15] Michalic, S. (2004). The importance of implementation fidelity. Emotional \& Behavioral Disorders in Youth. Fall, 4(4):81-109.

[16] Center on Instruction/National High School Center (2010). Aligning Instruction (Vertically and to Standards) http://www.centerii.org/handbook/Resources/7_A_Aligning instruction.pdf (02.01.2017)

[17] Niedermeyer, F. \& Yelon, S. (1981). Los Angeles aligns instruction with essential skills. Educational Leadership. May, 38(8):618-620.

[18] Yıldırım, A. \& Şimşek, H. (2013). Sosyal Bilimlerde Nitel Araştırma Yöntemleri. 6. Baskı, Ankara: Seçkin.

[19] Karataş, Z. (2015). Sosyal bilimlerde nitel araştırma yöntemleri. Manevi Temelli Sosyal Hizmet Araştırmaları Dergisi. 1(1): 62-80.

http://www.academia.edu/3621577/Sosyal_Bilimlerde Nitel Ara\%C5\%9Ft $\%$ C4\%B1rma_Y\%C3\%B6ntemleri_Qualitative _Research_Methods_in_Social_Sciences (10.07.2015)

[20] Hill, T. C. (2013). Common Formative Assessments Developed Through Professional Learning Communities (Plcs): A Case Study To Analyze The Alignment Of Curriculum, Assessment, And İnstruction In A Math Plc At A Title I Middle School In The Southern United States. (Unpublished doctoral dissertation). University of Texas A\&M/Office of Graduate Studies, Texas, p.21.

[21] Şenel, H. G. (2004). Öğretmenlerin ilkokuma-yazma öğretiminde tercih ettikleri yöntemler. İlköğretim-Online, $3(2): 48-53$.

file://C:/Users/acer/Downloads/5000038388-5000053942-1PB.pdf (10.07.2015)

[22] Rençber, İ. (2008). Yeni İlköğretim Programının Uygulanmasında Karşılaşılan Sorunlara İlişkin Müfettiş, Yönetici ve Öğretmen Görüşleri. (Konya İli Örneği). (Yayımlanmamış yüksek lisans tezi). Selçuk Üniversitesi/Sosyal Bilimler Enstitüsü. Konya.

[23] Ankara İli Zümre Başkanları Toplantısı Raporu (2015). 2015-2015 Eğitim-Öğretim Yılı İl Zümre Raporu, Ankara http://nasuhpasailkokulu.meb.k12.tr/meb_iys_dosyalar/06/20/ 708308/dosyalar/2015_04/13020906_zmredeerlendirme2.doc $\mathrm{x}(24.07 .2015)$

[24] Taşdemir, M. \& Taşdemir, A. (2007). Mesleki sürecin bazi boyutlarina ilişkin sinif öğretmenlerinin görüşleri. SAU Eğitim Fakültesi Dergisi, 14:161-174. 
[25] Caner, A. \& Tertemiz, N. (2010). Uygulamayı etkileyen faktörler açısından ilköğretim 1. kademe öğretim programları uygulamalarının değerlendirilmesi: sınıf öğretmeni görüşleri. Türkiye Sosyal Araştırmalar Dergisi, Ağustos, 14(2):155-187.

[26] Yalar, T. (2010). İlköğretim 3. sinıflarda Türkçe dersi ögretiminde karşlaşılan sorunların öğretmen görüşlerine göre belirlenmesi. Dicle Üniversitesi Ziya Gökalp Eğitim Fakültesi Dergisi, 15:30-41.

i This paper has been produced from second author's counseling by first author's doctoral thesis named as "Teacher's Curriculum Alignment and An Analysis of the Factors Affecting Curriculum Alignment (The Case of Secondary School Grade 5 Science Lesson)
[27] Özdemir, S. M. (2008). Yeni ilköğretim programlarinin birleştirilmiş siniflarda uygulanabilirliğine ilişkin nitel bir çalişma. 17. Ulusal Eğitim Bilimleri Kongresi, 01-03 Eylül, Sakarya.

[28] Warring, D. F. (2015). Teacher evaluations: use or misuse? Universal Journal of Educational Research 3(10): 703-709, 2015 http://www.hrpub.org DOI: 10.13189/ujer.2015.031007 